\title{
Sigurd Kloppenborg Skrumsagers oplevelser og tanker fra sin deltagelse under 1. Verdenskrig
}

Af Jens SKrumsager SKau

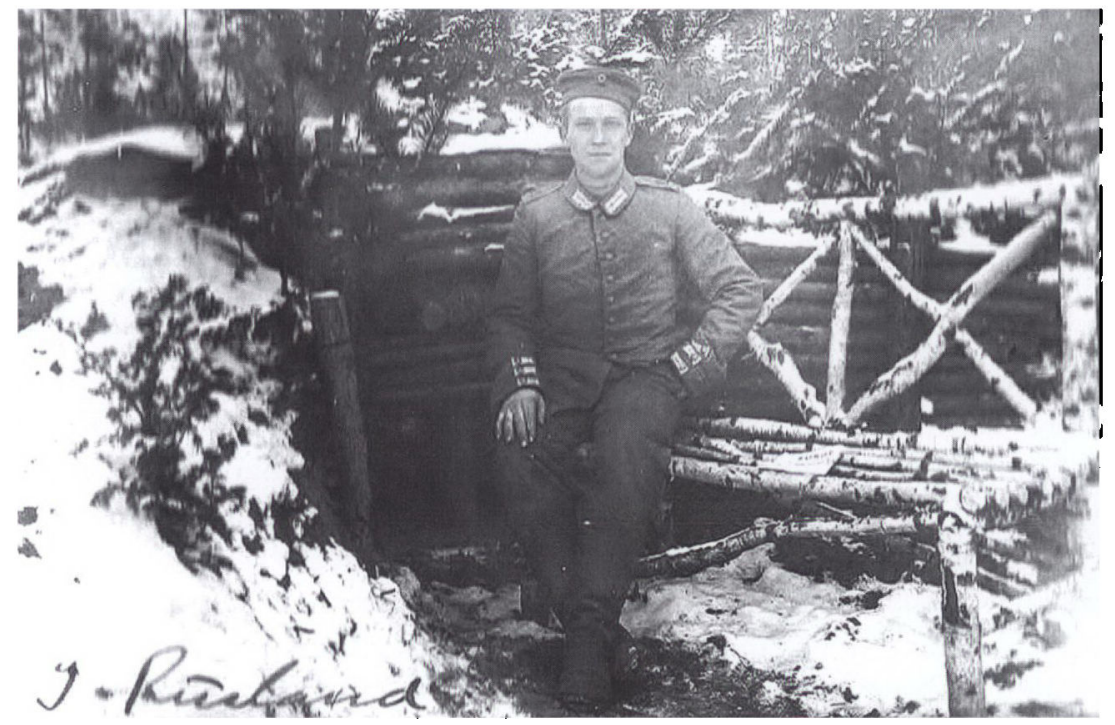

Sigurd Kloppenborg Skrumsager i Rusland 1916

Ved Lens i kamp ved Vestfronten, 31. januar 1917: „Der kan komme øjeblikke, hvor man synes, at det hele kan være ligegyldigt, og da er det hele let og man kan spøge og være $i$ humør. - Dog er den letteste vej ikke den rigtige, føler jeg godt. Med alle disse grublerier kommer man selv til kort - sit sted, hvor man går hen med dem og finder fred - så er menneskers magt og vilje jo dog kun lille og svag.«

\section{Indledning}

Sigurd var min morbror. Ud fra hans godt 1.000 breve fra krigsfronterne under 1 . Verdenskrig, som han skrev og sendte til sine forældre 
og søskende fra sin lange periode i tysk krigstjeneste, har jeg beskrevet hans oplevelser og tanker. I august 1914 rejste han til en by nær Berlin og blev indkaldt til session 1. oktober 1914 og indkaldt til militærtjeneste 12. november i Berlin. 18. marts 1915 blev Sigurd beordret til Østfronten, hvor han var indtil 4. december 1916, hvor han blev overflyttet til Vestfronten. Her var han ved fronten mellem Lens og Arras. Han blev alvorligt syg i de sidste dage af marts 1917, indlagt på krigslazaret nr. $23 \mathrm{i}$ Ath og i august overført til Elberfeld. I november 1917 kom han endelig hjem til Københoved på rekreation, og den tyske krigstjeneste var dermed slut for ham.

En væsentlig kilde til fortællingen er tillige 15 breve fra læge Hans Lausten-Thomsen til Sigurds forældre, hvori lægen hver dag udførligt redegjorde for Sigurds sygdom og udvikling. Læge Hans LaustenThomsen gjorde tjeneste på krigslazaret nr. 23 i Ath, hvor Sigurd som nævnt blev indlagt i marts 1917.

For at få fuldt udbytte af historien skal man helst have en forhåndsviden om landsdelen Slesvig efter 1864 og et vist kendskab til de alliancer, som førte til, at 1 . Verdenskrig brød ud 1. august 1914 og varede til 11. november 1918.

Sigurd Kloppenborg Skrumsager blev født på Bejstrupgård 6. juli 1894. Han var den ældste af en børneflok på fem. De voksede op sammen på Bejstrupgård i Københoved, som ligger lige syd for Kongeåen.

Sigurd ønskede at komme ind ved garden i Berlin. Han havde søgt, men fået afslag, fordi de lokale myndigheder havde tiltænkt ham med hans sindelag noget meget mere "passende«. Sigurd rejste derfor til Halle i Sachsen i sommeren 1914 og meldte sig som bosiddende på en gård, hvor han som volontør arbejdede ved landbruget. Ved at flytte sikrede han sig at skulle på session i Berlin.

Sigurd var dansksindet, men tysk statsborger, fordi han blev født $i$ den tabte danske landsdel Slesvig-Holsten. Han var dermed forpligtet til at blive tysk soldat, medmindre han ville stikke af over grænsen. Det kunne have den alvorlige konsekvens, hvis Tyskland fortsat bevarede herredømmet over landsdelen, at han ligesom alle andre ikke senere ville kunne vende tilbage til sin hjemstavn og for eksempel overtage den fædrene gård. Det var således ikke med den gode vilje, at Sigurd gik i krig på tysk side. Nødvendigheden for at sikre dansksindede $\mathrm{i}$ landsdelen krævede det. For hvis Tyskland vandt, ville landsdelen under alle omstændigheder fortsat være en del af Tysk- 
land, og han ville sandsynligvis aldrig kunne komme tilbage til hjemstavnen. Nu gik det heldigvis anderledes. Tyskland tabte krigen, og fredstraktaten indgået $i$ Versailles gav mulighed for en folkeafstemning. Ved folkeafstemningen 10. februar 1920 i 1 . Zone - der svarer til det nuværende Sønderjylland - stemte 75 procent for, at Sønderjylland blev genforenet med Danmark.

30.000 dansksindede mænd var under 1 . Verdenskrig i tysk krigstjeneste, og godt 5.000 mistede livet for en sag, som ikke var deres. Det er svært at sætte tal på, hvor mange der overlevede med sår på sjæl og legeme. Men mange dansksindede havde været under pikkelhuen og mere eller mindre modvilligt aflagt eden til den tyske kejser mellem 1864 og 1918.

Det er interessant, at Sigurd i sine breve aldrig nævner, at han har skudt med sit gevær ved fronten, har skudt på nogen, eller bare skudt for at overleve. Han lægger heller ikke skjul på, at han sympatiserede med »fjenden«, når det gik dem godt.

\section{Uddrag af Sigurds 1.000 breve fra kort før indkaldelsen til session i Berlin til krigen var slut for ham i december 1917}

Uden sine forældres viden tog Sigurd hold om sin egen skæbne. Han rejste til Sachsen i sommeren 1914 før 1. Verdenskrigs udbrud, fordi han ville være soldat $i$ Berlin, og han ønskede at komme til "gardens Kraftwagenabteilung « for at få mulighed for at køre lastbil og bil som soldat.

Halle, 18. august 1914: "Jeg har spurgt og fået at vide, at det vil tage 3 til 4 uger at få uddannelsen til at køre bil og opnå kørekort, og det vil jeg gerne. Men et kørekort vil koste 160 Mark og med logi, mad og lommepenge vil det nok beløbe sig til 250 Mark. Det er ikke småting, og jeg håber, at I vil overveje det og sende pengene. Jeg vil ikke lægge nogen tvang på jer og håber dog på det bedste udfald, men et kørekort har jo også sine store fordele. Jeg kan komme til Kraftwagenabteilung i Berlin, når jeg skal være soldat. Sker det, vil jeg komme til at køre med officerer og mandskab osv. Sidenhen når det er overstået, vil jeg sikkert få brug for kørekortet. «

Halle, 30. august 1914: "Der er hårde kampe på Balkan, og jeg kan læse og høre, at der i Østpreussen kæmpes uden tvivl stærkt [ved 
Tannenberg, 26.-30. august, JSS]. Mange landsmænd må sikkert der gøre »deres tunge pligt «. Her er der stadig stor begejstring. Der flages dag og nat og synges nationale sange, og der vises i det hele et varmt og trofast sindelag, som er prisværdigt og må fylde enhver med agtelse og ærbødighed. Bylivet synes jeg i mange henseender godt om. Der er mere fart og flüge over det hele, og folk er mere vågne og lever mere end landboerne. Landlivet har dog for mig langt de største fortrin. Nu må jeg ud at gå en tur i det dejlige vejr og måske i aften i teater. [...] middagsmaden her er tarvelig og smudsig tillavet. Den består altid af en slags suppe, der ligner opvaskevand og er fyldt med grøntsager, kød, melboller som sneboller og alt mulig, og ofte serveres maden $i$ det vaskefad, som vi alle bruger at vaske os i."

Halle, 13. september 1914: "Den forfærdelige krig går sin gang og sætter sine spor overalt. Jeg har vurderet situationen nøje og mit ønske er: 1) Hurtigst muligt at blive færdig med militærtjenesten, 2) Ikke unødig gå med i krigen. 3) Lagt planer for de tænkelige tilfælde lom han tænker på at flygte? - det tror jeg ikke, JSS], men ikke alt kan man skrive, og måske er jeg allerede gået for vidt.«

Brachstedt nær Halle, 24. september 1914: »Nu har jeg fået arbejde og får 1 mark om dagen. Endelig har jeg fået indkaldelse til session og skal stille den 2. oktober 1914. Krigen er i fuld gang - og kampene bringer ikke altid sejre og dermed truer min indkaldelse til fronten." [Kampen ved De Masuriske Søer, JSS].

Halle, 2. oktober 1914: »Kommer lige fra session og vil straks meddele resultaterne. Jeg bad om at komme til Garde-Trainet, men det blev der ikke taget hensyn til. Derimod råbte man straks Garde Artilleri og derpå Garde Kürassier [kavaleri - heste, JSS] og man mente, at noget bedre kunne jeg ikke ønske, men i en fart skød jeg så ind, at så ville jeg hellere til fods (dann mach ich lieber laufen), og sessionsherrerne sagde så i spøg: Lass ihn denn laufen, Garder Infanteri I, og så var loddet kastet. Gik det ikke efter de bedste ønsker, så er det dog en trøst, at det kunne have gået meget dårligere, og jeg er nu ikke så utilfreds med resultatet."

[Sigurd fik lov til at tage en tur hjem til Kobenhoved efter sessionen 2. oktober. 12. november fik han besked om straks at stille som rekrut i Berlin. Men han ville forst til Halle efter sit habengut, JSS]. 


\section{Berlin}

Berlin, lordag aften 14. november 1914: "Har nu endelig overstået en lang travl dag. Stillet mig på mobiliseringspladsen $\mathrm{kl} .7$ sammen med mange hundrede andre rekrutter. Travet meget rundt. I morgen skal vi iklædes. Ligger på stue med 11 andre - mest Rheinlændere. Adressen her i Berlin er: Kaiser Franz Josef Garder Grenadier, Regiment Nr. 2, Blüchenstrasse, Rekruttendepot 1,d, Kaserne 3, Berlin.«

Feltpost fra Berlin, 18. november 1914: »Nu har vi fået udleveret klædninger, men de er gamle og forslidte fra omkring år 1900. Man kan stoppe, vaske og pudse i en uendelighed. Her på vores stue er vi nu 50, deriblandt et par studenter, ellers mest købmand og andre byfolk, ingen landmænd uden mig. Har min seng under en stor orn en slem modsætning til hjemme. Landsmænd har jeg endnu ikke fundet. Hvis vi spørger til krigen, får vi svaret: »Den er vi snart færdige med. Snart går vi mod England. « Der meldes om en sejr, men ellers kan jeg ikke blive klar over noget. Der flages, og der kimes med byens mange klokker. Jeg har brug for pudselapper, et kort over Berlin, og lidt smør og kød, men det haster ikke."

Feltpost fra Berlin, 22. november 1914: »Jeg må holde godt øje med mine sager. At stjæle og rapse er en ærlig sag her, og det undrer mig, at man kan være så hensynsløs mod sine kammerater. Mine sager har jeg dog holdt godt sammen på indtil nu.[...] Vi har nu fået geværer, bajonetter og overfrakker samt en del mere tøj. Her er ingen landsmænd."

Berlin, 1. december 1914: "En af vore flinkeste feldwebler gik rundt på stuerne for at høre, hvor vi var fra. Da han hørte, at jeg var fra Nordslesvig, tiltalte han mig på dansk. Jeg lod mig dog ikke mærke med noget og blev heller ikke klog på, hvor han var fra. Senere kom jeg dog tilfældigvis til at se en postpakke fra Højer til en Garde Bossen. Senere fik jeg manden opsporet, og det er dejligt at træffe en landsmand, den eneste ved regimentet."

Berlin, 6. december 1914: "Der er meget driveri - for dem, som er vant til at arbejde. Man bliver vænnet til tålmodighed og til at vente i timevis. Endvidere er det jo soldatens første bud at trykke sig, hvor man kan. Masser af pudsearbejde. I går var vi en tur omkring Siegessäulen på Königplatz foran Rigsdagen, Unter den Linden og Friederichsstrasse og morede os kostelig over gadelivet. Næsten halvdelen på stuen er katolske, og der gives mange fromme og tiltalende folk 
Sigurd i uniform.

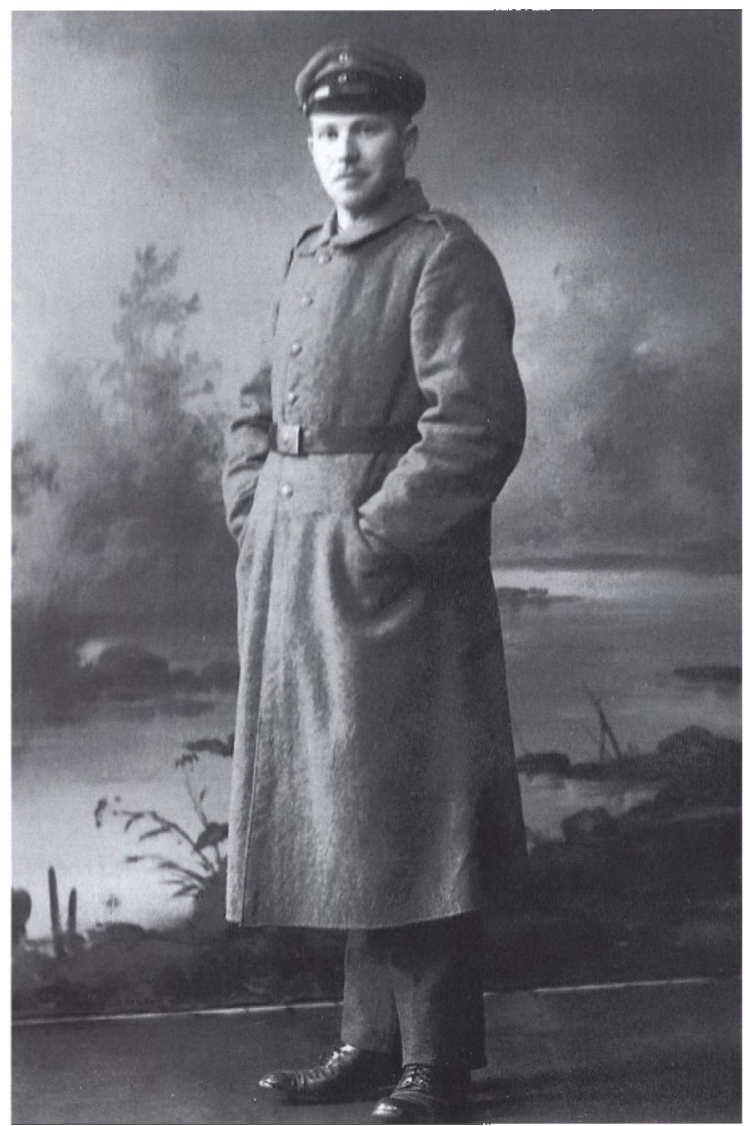

mellem dem, mere end blandt de evangeliske der gennemgående står fjernt fra kirken.«

Berlin, 8. december 1914: »Kære Mor. Her er lige en pakke med vasketøj og håber, at jeg kan få det tilbage inden alt for længe. Jeg mangler ellers intet, men et par underbukser kunne jeg godt bruge."

Berlin, 13. december 1914: „Vi får nok ikke juleorlov. Krigen går det fortsat langsomt med, og det er ikke meget opmuntrende at læse beretningerne. Russerne har jo gang på gang store tab. I dag meldes der endog om et tab på 150.000 mand. [Det må være kampen ved Lodz $i$ slutningen af november og $i$ begyndelsen af december 1914. Tyskernes tab var på 140.000, JSS]. Her fra regimentet rykker der en af dagene igen 
nye forstærkninger ud. Inden længe skal vi nok tages i ed. Vi er blevet vaccineret mod kolera og tyfus. Det går næsten til på samme måde, som når vi driver kalve ind og sprøjter. Huden foldes sammen på brystet, og så får vi en indsprøjtning. Bagefter blev vi alle mere eller mindre dårlige, og flere segnede om og kom på lazarettet. Inden længe skal vi nok også tages i ed.«

Berlin, 17. december 1914: "Tak for vasketøjet [sandsynligvis retur fra Sigurds sending den 8. december, JSS]. Julen nærmer sig, og vi landsmænd vil nok finde sammen for at holde jul. [...] Send ikke for meget til mig. En lille bog med underholdende læsning er meget kærkommen. Vi skal nu til at have marchøvelser, som kan være meget godt til en afveksling."

Berlin, 19. december 1914: "Rygter om at videreuddannelsen for os skal ske et andet sted end i Berlin fra den 28. december. Her går rygter om, at man har fanget 500.000 russere, og der flages som aldrig før. Endnu er vi ikke taget i ed, men det sker nok en af dagene.«

Berlin, 22. december 1914: "Sender min bedste julehilsen, skønt det kniber mig meget at komme i julestemning. Rygte om, at vi skal afrejse den 28. december - måske vestpå. Jeg tænker nu på at få min næse kureret, hvis det bliver muligt. Så ligetil er det ikke, da der er så mange, der får sådanne tilfælde, selv officerer. Begejstringen er ikke så stor længere.«

Berlin, 26. december 1914: "Juleaften kom der telegram om, at vi skulle gøre os mobile, da vi sikkert skulle rykke ud den 28., så nu er det givet, at vi skal bort. Om jeg kommer med, vil tiden vise, men i dag har jeg meldt mig med min næse, som volder mig problemer. Den er dog ikke blevet undersøgt, da der ingen læger var på lazarettet. Kammeraterne skelede selvfølgelig lidt til mig, da jeg meldte mig, men de tænker dog ikke på at skade mig og kan da heller ikke gøre det. Det var en mærkelig jul, hvor toppen var, at der var fri ol til festen.«

Berlin, 27. december 1914: »I formiddag begyndte så vores iklædning. Først modtog vi vores lønningsbog til felten, blev så iklædt i feltgrå fra top til tå, fineste ting med stempler fra 1909 - 10 og 11 osv., så fra den tid havde det allerede ligget færdig. Om eftermiddagen så vores feltwebel listerne efter for at se, om vort kompagni var fuldtallig, og fandt så, at jeg havde meldt mig syg. Han kaldte mig så straks hen til sig og spurgte, om jeg mente, jeg kunne tage med. Jeg mente så, at det var bedre, at jeg fik min næse kureret. Efter at vi havde talt 
lidt frem og tilbage, blev vi enige om, at jeg skulle blive tilbage og en anden tage af sted i stedet for. Jeg måtte så afgive mine sager og gik så $\mathrm{i}$ byen om aftenen og fandt landsmænd. I dag skulle jeg så have været undersøgt, men lægen var atter borte. Nu er jeg sammen med mine kammerater, der rykker ud i morgen, antagelig til Vestfronten. De har travlt med at pakke, og jeg har ikke meget at tage mig til. Jeg håber på at kunne blive på kasernen til februar, når far kommer til Berlin." [Sigurds far, Hans Diderik Kloppenborg-Skrumsager, blev medlem af Den preussiske Landdag valgt af dansksindede i 1908, JSSl.

Berlin, 28. december 1914: »Tjenesten falder mig hverken svær eller særlig kedsommeligt. Mange naragtigheder er der jo ved det, men dem har man jo lov til at more sig over. Vi eksercerer og har øvelser dagligt på Tempelhofer Plads. Endvidere er vi begyndt at skyde. Vores våben er belgiske, både bøsserne og bajonetterne, og de bærer præg af krigens skrammer - vemodigt er det at tænke derpå.«

Berlin, 29. december 1914: "Jeg sidder lige og venter på at høre fra jer, og om mine sidste breve har nået jer. I disse dage er jeg stærkt optaget af min næsehistorie, som nu skrider langsomt og sikkert frem og tegner til at bringe et godt resultat. Der er konstateret en S-formet forhøjning af næseskillevæggen. Tilfældet skulle være meget almindeligt og kan afhjælpes ved en lille operation. De andre er klar til at tage af sted til fronten, hver time, muligvis sker det i nat. Denne gang kommer jeg ikke med, og hvornår det vil ske, vil tiden vise. Jeg er glad ved tiden, der er gået, og håber også på en god fremtid."

Berlin, 31. december 1914: "Der er fyldt med nye rekrutter overalt. Nogle er nogle små nogen, der kun er 1,58 meter høje. Næsehistorien. I går skulle jeg have været til overlægen, men da vi skulle tages i ed, måtte jeg vente til i dag, og resultatet blev knapt, som jeg havde ventet. Lægen sagde, at der ikke var noget $i$ vejen, og at jeg måtte have min tjeneste med. Nu skal jeg så begynde uddannelse sammen med de nye rekrutter - og vente på bedre tider. Kammeraterne, som skulle have været bort den 28 . december, er her endnu, men stadig mobile og kan skride hvert øjeblik. Vi får ikke lov til at gå ud i aften, da det er nytårsaften.«

Berlin, på vagten 4. januar 1915: „Efterretningen var meget trist at modtage og har vel bragt stor sorg derhjemme hos jer, og det må jo være svært for faster Kirsten at bære. Tiderne er så oprevne, og der sker så meget skrækkeligt, at ens følelser bliver så afstumpede, at der skal meget til virkelig at gøre dybe indtryk. [Sigurds onkel, Johan Clau- 
sen, gift med faster Kirsten, faldt $i$ Vestflandern 22. december 1914 og begravet samme sted. Der blev holdt mindehøjtidelighed $i$ Rødding Frimenighed 6. januar 1915. Johan Clausens navn er næont på mindestenen $i$ Rødding for de faldne, JSSJ. I dag er vi på vagt på automobilparken, og jeg har lejlighed til at se, hvordan det er ved disse tropper. Jeg har nemlig tænkt at komme her. Næsen bragte altså intet resultat, men jeg er dog ved frejdigt mod og lider ingen nød.«

Berlin, 9. januar 1915: "Jeg er i forgårs aften blevet sendt på lazarettet, da jeg havde meldt mig syg. Lægen mente, at det var lidt influenza og forkelelse."

Berlin, 11. januar 1915: »Jeg er kommet ud af sengen og ved godt mod. Tankerne har stadig søgt hjem til jer. Det må være svære tider for faster Kirsten og for jer alle, jeg vil gerne bringe jer min bedste trøst. Værst er sådan en tid vel altid for dem, der måtte blive hjemme. Dem, der derimod står i hede kampe, er så optaget, at meget af det tunge helt glemmes. Sådan føler jeg det i hvert fald personligt. Jeg søger stadig at fægte mig så godt som mulig igennem, og jeg har altid den største tro til, at det nok skal gå godt, når man bare gør ens bedste. Jeg tænker på, at det måske havde været bedre at være ved kavaleriet."

Berlin, 12. januar 1915 (to breve): "Jeg er endnu på lazarettet, hvor jeg har det godt og kan forvente at blive et par dage endnu. " II brevet gor Sigurd sig nye overvejelser om en stilling i militæret som chauffor og næoner, at infanteritjenesten er den mest udsatte, JSS].

Berlin, 13. januar 1915: »Lægen har nu lige gjort sin runde her på lazarettet, og han mente, jeg kunne godt blive her en dag eller to endnu. Betjeningen udføres af Røde Kors søstre. De er venlige og muntre og gør meget ud af deres soldater. På stuen her er vi næsten alle raske, og lægerne benyttede os forleden til forsøg, hvad dog ikke var meget slemt. Der blev taget en blodprøve af os for at se, hvorledes vaccinationerne havde virket. Jeg er selv blevet vaccineret 4 gange mod tyfus, kolera og kopper, så vidt jeg ved, og der er jo ingen skade ved at være det.«

Berlin, 14. januar 1915: "Skønt jeg ikke oplever så meget her på lazarettet, har vi dog en grammofon og en papegøje. Og så findes der desuden et bibliotek, hvor man kan finde lidt læsning. Tre gange om dagen kommer aviskonen med aviser, og hun har som offentlig hemmelighed lidt godter med. Det finder hun god afsætning for.«

Berlin, 16. januar 1915: "Jeg lider ingen nød. Jeg har taget 3 pund 
på, så I forstår, at vi ikke lider nød. Så jeg er godt tilfreds her, men ved dog ikke endnu, hvor længe det kan vare. [...] Den 4. januar rømmedes Ersatz Bataljonen og blev da udfyldt af de krigsfrivillige (også et depot), samt de sørgelige rester af mit gamle depot 1a, hvor jeg også var med. Vi var vist 4-5 mand, hvoraf nogle havde været på lazarettet. I Ersatz Bataljonen har vi meget mere tjeneste end i rekrutdepotet, og alt går mere stramt til, da vi har de mange gamle og sårede. Soldaterne, som nu er i Ersatz Bataljonen, er meget dårligere. Jeg er glad for, at jeg ikke behøver at bimse med dem, da de ikke kan noget alligevel.«

Berlin, 18. januar 1915: „Opbruddet fra lazarettet skete, før jeg havde ventet det, nemlig i formiddags. Vi måtte tage afsked, hvor svært det end var, men håbede dog alle på gensyn. Nu er jeg tilbage i Ersatz Regimentet.«

Berlin, 22. januar 1915: "Det fryser og sner og er rigtig vintervejr. Vi făr virkelig at føle, hvad det betyder at være soldat - som kvæg her.«

Berlin, 25. januar 1915: »Et godt glas øl har jeg ved siden til at hæve humøret. Det går stadig stramt til i kompagniet. Lige for et øjeblik siden havde vi appel i feltmæssig beklædning, og nu er det straks sengetid. Penge mangler jeg ikke. Jeg har 25 mark og tjener jo 33 pfennig om dagen."

Berlin, 27. januar 1915: "Det er Kejserens fødselsdag i dag. Obersten sagde et par ord, der selvfølgelig endte med et leve for kejseren. I fredstid fejres kejserens fødselsdag på en hel anden og festlig måde, siger de gamle. At marchere gennem byen er altid morsomt. Berlinerne er jo glade for deres soldater og viser os megen venlighed. Undertiden kan der flyve appelsiner, cigaretter og cigarer ud i vores kolonner. Et kompagni på 250 er lige rykket til Vestfronten.«

Berlin, 3. februar 1915 - brevkort til sin mor: "Traf så atter sammen med far i aftes. Vi var i Habsburger Hof. I morgen rykker der en større transport af til fronten."

Berlin, 7. februar 1915 - brev til sin mor: "Når du modtager dette brev, er far vel her, og vi kan være sammen, som jeg har glædet mig til i så lang tid. Jeg er nu i gang med at få mulighed for bilkørsel. Har meldt mig straks til bilbataljonen, og jeg venter nu på at blive antaget. Der var mange, der meldte sig, men der er kun få, som har eksamensbevis som jeg. Så jeg venter at blive antaget, også selv om de frivillige har forsteret. Det er nogle slemme karle - de krigsfrivillige - løber rundt på kasernen, og de bliver da også kaldt frivillige »brødspisere«. 
[...] I går aftes fik jeg endelig orlov. Vi var $\mathbf{i}$ teater og så Strindbergs »Rausch«. Et berømt og meget dybsindigt stykke.«

Berlin, 13. februar 1915: "Jeg kan jo ellers sagtens, nu far er her, hver aften fin aftensmad, og vel nok en gang imellem lidt orlov, så vi kan se os lidt om. I aftes kom der en kedelig beretning fra Østfronten. Det er for galt, at det stadig er sådan. [Kampen ved Masuriske Søer tidligere Østpreussen, nu Polen. Tyskerne mistede 16.000 og russerne 54.000 mand, JSS].

Berlin, 7. marts 1915 - brev til sin mor: "Hele vort kompagni på ca. 50 stykker rykkede $\mathrm{i}$ felten sidste fredag. $\mathrm{Vi}$, der er blevet tilbage, har nu i går måttet gøre stuer og gange grundigt rene. Næste tranport afgår den 20. marts, og jeg håber, at jeg til den tid er blevet afkommanderet. Ellers bliver det kritisk for mig. I aftes var jeg sammen med far og N.N. i Wintergarden, og vi morede os helt godt for en stund. [N.N. er formentlig Nis Nissen, dansksindet landdagskollega til Sigurds far, JSS]. Krigen er det jo stadig det samme med, ingen tegn på forestående afgørelse. [...] Kun synes tyskerne at få grundig bank, og det kunne jo være en hel opmuntring, om det skete."

Berlin, 13. marts 1915 - brev til sin far: »Jeg har haft besøg af Hans Gram, som siger, at han ikke kan skaffe mig et chaufførjob, men at han mener, at min far gennem officerernes forbindelser $i$ Landdagen måske kan. Desuden sagde han, at jeg selv burde tale med feltweblen om det.« [Hans Gram grundlagde $i 1901$ Bdrd. Gram $i$ Vojens, og var ogsa indkaldt under 1. Verdenskrig, JSS].

Berlin, 15. marts 1915: »Kære far og mor! Er i formiddag pludselig blevet udtaget til at gå med i felten og har så måttet iklæde mig. Jeg har stadig søgt at få lejlighed til at komme ud af kasernen og lige sende jer et telegram, så I kunne tage stilling til det, men jeg får det vist ikke gjort inden $\mathrm{i}$ aften.[...] Et pludseligt tilfælde med næsen er ret umuligt og ville sætte mig i en dårlig stilling. Som I kan se, står jeg allerede i begreb med at skulle af sted. Jeg har talt med underofficeren, og han mente, at det kunne have været bragt i orden, hvis far ved hjælp af en officer kunne have fået lidt indflydelse på bataljonen. Dagen har selvfølgelig været kritisk, men jeg er nu rolig og tryg og betror mig til Guds førelse og dernæst soldat uforknyt. Vær nu ved godt mod. Alt skal nok gå godt."

Østbanegården i Berlin, 17. marts 1915 klokken 21:20: »Jeg sidder nu i vinduet og venter efter jer, men nu har jeg snart opgivet det, derfor en sidste hilsen herfra. Vær ved godt mod og kun rolig, alt 


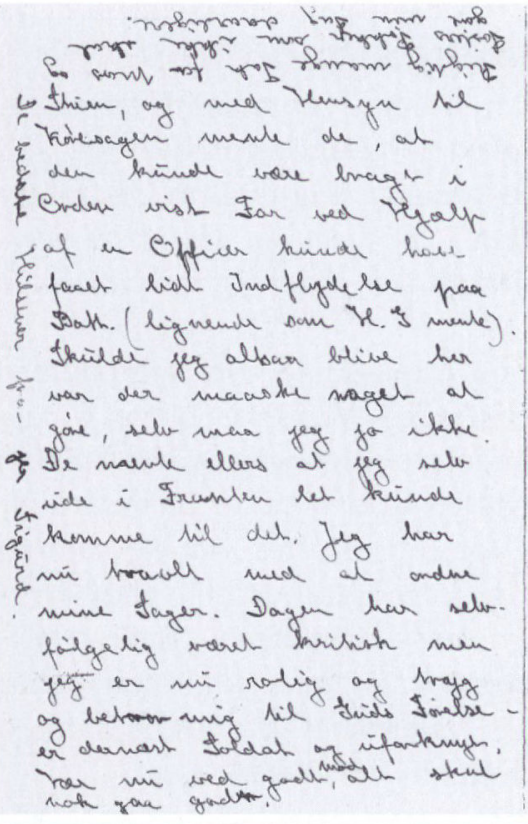

Barlin a. $15 / 316$.

Kare Far og Mon!

Er i Formiddags plindselig bleven indtagen Mil at gaa med i Jelten oy

har san mi maather lade unig iblase hoormed fey hat hafe twach. inethil mi onkring ke. Th da wi in ellwen overlader hide. ist as sebr. Jeg har stadig sige al far heylighed Mil al homme ind of kasionen og hige seude fer it jer frilling hil abs men jey fuar des wish iblue gyont indeu i Afren, them kaldes tid at autrade hovert Gigeblik det that vore. Jey har sebofollgetig sigh as gime min Bligh sue gadl jeg formacede, men kinade ibla halde mig suere. Feldweblen har feg tuls hide med men

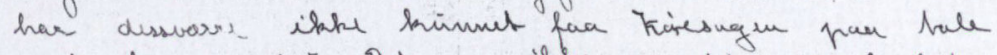

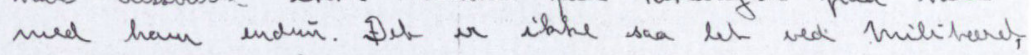
- mil Proke brender han jo gadt nok, sua gey the sach gade han premfore det. Yan heblagede i Day at

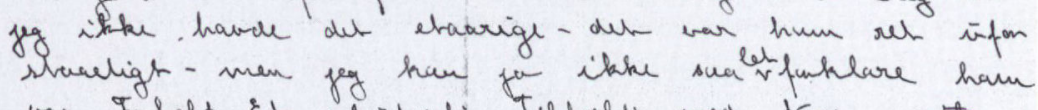

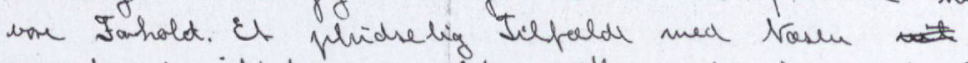
on rel imiligh ay vilde sathe mig i en duartig Shilling. - Sam a bum se straen gey oltowe i

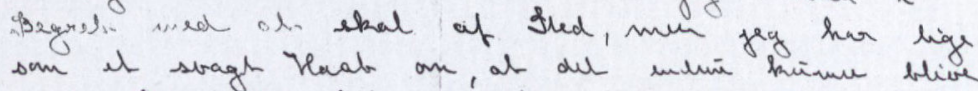
opout. - Jeg bulte lide med tuderuffecterni hen pan

Sigurds brev af 15. marts 1915 til forældrene, lige inden han bliver sendt til Østfronten. 
skal nok gå sin rigtige gang. De bedste hilsner til jer alle fra jeres Sigurd Kl. Skrumsager.« [Sigurd fik sandsynligvis sendt et telegram 15. marts om aftenen til sine forældre, og muligvis er de skyndsomt rejst til Berlin for at hilse af, inden Sigurd skulle af sted til fronten. Sigurd har vel haft et spinkelt häb om, at hans far kunne hindre hans afrejse til fronten, JSS].

\section{Ved Østfronten}

Østpreussen, på vej med toget 18. marts 1915 om morgenen: „Stadig bumler vi af sted gennem et ensformigt landskab, alt er hvidt, og det fryser godt. Kamppladserne har vi endnu ikke nået, men vi har dog passeret fæstningsværker.«

Insterburg, 18. marts 1915 [ $i$ det tidligere Østpreussen og det nuværende Tjernjakhovsk i Kaliningrad, JSS]. "Vi har kørt i tog og ikke set meget af krigens spor. Russerne har været her $\mathrm{i}$ tre uger uden at ødelægge noget af betydning. I aften ser det fredeligt ud - det fryser godt, og alt er klædt i hvidt."

Cafe Hansa i Insterburg, 19. marts 1915: "Sidder lige nu på en fin cafe $i$ selskab med en angelbo og en fra Vestpreussen - et rigtig godt selskab, og vi forstår hinanden udmærket. Hvad der ellers vil ske, aner vi ikke, men vi er godt tilfredse her og lader komme, hvad der vil.«

Gumbinnen, 20. marts 1915: [det nuværende Gusev i Kaliningrad, JSS]. »Nu i dag videre på vej til fronten - hvorhen vides ikke. Har nu passeret flere pladser, hvor der har fundet fægtninger sted - skyttegrave, krigergrave og afbrændte huse ser man jævnligt. Humøret efter omstændighederne upåklageligt. Meningsytringer nu ganske frie. Alt står ellers vel til. Med det bedste håb drager vi af sted."

Suwalki, 21. marts 1915: [I den nordøstlige del af Polen, JSS]. „Endnu er vi stadig på vej til fronten og holder for øjeblikket lige på grænsen ved Suwalki, men hvor vi til sidst kommer hen, ved vi ikke. Landet her er forladt og byerne plyndrede og nedbrændte. Tankerne søger dog hjem til jer - vær I rolige og trygge, alt går sin gang, som det skal, og der er intet at ændre."

22. marts 1915: "Ligger nu i reserven tæt ved fronten ved Augustow [i den nordøstlige del af Polen syd for Suwalki, JSS]. Det er nu tøvejr og et vældigt pløre. Men vi ser og oplever meget, som vi ikke har gjort før.« 
På forpost ved Augustow i Polen, 24. marts 1915: „Det er gået rask med at komme til fronten. Vores kompagni fik $\mathrm{i}$ aftes en forpoststilling en 6-7 km foran vores egentlige hovedstilling. Vore poster ligger langs med en å lige over for russerne, som vi stadig hører arbejde $\mathrm{i}$ deres skyttegrave. Selv havde jeg fået en patrulje ved en sprængt bro, som russerne afgav nogle salver på, kort efter at jeg var blevet afløst. Alt blev derved alarmeret, men snart blev der dog ro igen. Om dagen ligger vi og hviler $i$ et lille hus $i$ en skovlund, men om natten må vi gå frem på vore poster. $\mathrm{Nu}$ ser og oplever man jo selv meget skrækkeligt, og man hører om det i denne tid. Rart er det virkelig ikke, og det kan jo synes så uforståeligt, at man er tvungen ned i sådan en stilling. Det er en prøvelsestid, som dog nok skal have sin grund, og som man ikke kan komme uden om. Mange sådanne tanker kommer nemt, når man ligger på så udsatte poster. Man bliver lille og ydmyg og betror sig til Guds varetægt. Jeg er derfor også tryg i hvad fare, jeg så end er i, og glæder mig til en god fredens tid bagefter. - Her på forposten ligger vi i 48 timer ad gangen og ligger lige så længe i hovedstillingen bagved. Angreb fra vores side er der ikke tale om, men det modsatte vil nok snart ske, da vi ligger i en kile af fronten nogle kilometer bag ved Augustow. Det hedder sig, at vi snart skal flytte et andet sted hen. Der kunne være meget at fortælle herfra, men hvor stor pressefriheden egentlig er, er jeg knap klar over, og om jeg overhovedet kan give mig af med sådan brevveksling, er virkelig et stort spørgsmål. Det vil derfor være mig meget brugeligt, når jeg først hører, at I modtager mine breve. Så må jeg slutte - er ved godt mod og håber snart på et glad gensyn. Vær I kun trygge og bedes hilse fra jeres Sigurd.«

Augustow, 26. marts 1915: "Kære alle sammen! Vi ligger endnu stadig her ved Augustow og har det ret roligt. Selv har vi kun nogle patrulje sammenstød, som alle er løbet godt af. Til højre og venstre for os hører vi stadig en rolig kanonade, og en flyver lader sig undertiden se. Om aftenen ser man ildebrande og lyssignaler, men det er også det vigtigste af den slags ting. Fjenden selv er egentlig meget medgørlig og volder os ikke synderlige vanskeligheder, men de russiske forhold, som vi må leve under, er os næsten utålelige i alle måder. Forplejningen er det først galt med, navnlig med at få noget at drikke. Brønde har man næsten ikke, og dem der er, er usle, og vandet i dem så smudsige at man straks får diarré, når man drikker det. Vi må derfor først koge det, og det er besværligt og tager hele smagen fra 
det. Havde man bare lidt vand at drikke, så var man lykkelig. Med maden går det ellers nogenlunde som i kasernerne. - Vi har jo feltkøkkenet, som dog godt kunne lave sine sager lidt mere appetitligt og renligt. Mad og drikke er det, vi altid først må sørge for, hvis vi vil bestå. Selv kan vi nok koge lidt i vore kogekar, men der skal lidt erfaring til, inden det går rigtigt. De gamle karle får undertiden opsøgt et får eller andet, som vi kan holde måltidet på. Med logi er det ikke heller bedre. Den halve tid ligger vi på forposter og bor da for det meste $i$ huler og telt, og det kan jeg endda finde mig i. Den anden halve tid ligger vi $i$ reserven bag vor stilling og bor da $i$ en russisk landsby, der mest består af små forfaldne træhuse, som er så fulde af utøj og møg, at det er en helt pest. Husene er stærkt belagt, så vi knap kan ligge ned alle på en gang. Bohave har jeg aldrig set i dem, men det er vel sagtens ødelagt. Hele gulvet er overstrøet med halm, som vi så ligger og døser i. Det er et rædsomt svineri i sådan et kvarter - rundt om husene ligger der møg og affald fra slagtninger. Skind, indvolde, ben osv. Vejene er sådan, at man næsten ikke kan forestille sig det - nu da det tor, synker hjulene i til navene, og vi infanterister har møje med at slæbe os igennem. Undertiden er det hele oversvømmet. Der er så meget at fortælle, men jeg kommer lige fra vagt $\mathrm{i}$ nat og må derfor hen at sove ud til i aften, ellers går det galt. I dag skinner solen. Drikkevarer er det mest kærkomne. Så mine bedste påskehilsner til jer alle og en særlig lykønskning til bror Erik. Fra Sigurd.«

28. marts 1915: "I går måtte vores bataljon gå meget igennem. Det var en drøj march. Kl. 3 rykkede vi ud og nåede her $i$ kvarter, en gammel kaserne, om natten mellem 11 og 12. Jeg må tilstå, at jeg aldrig i mine dage har været så dødtræt som i aftes.[...] Og hjemme holder I bare søndag, jo var der bare fred, og jeg var hjemme igen.«

29. marts 1915: »Vi ligger endnu her i kvarter og kommer til kræfter efter marchen. Mine ønsker om mad er, at I ikke sender kødvarer eller røgvarer, men derimod smør, sukker, chokolade eller svesker, og pakkerne må kun veje et halvt pund. Det synes måske påtrængende, men I kan tro, at man først og fremmest må sørge for mad, hvis man skal komme godt igennem det hele. Enkelte har travlt med at fjerne det værste utøj af sig, og hver gang der gores en god fangst, er der stor glæde. Endnu har jeg ikke været plaget af det.«

Øst for Suwalki, 31. marts 1915: "Forleden nat blev vi pludselig med banen transporteret herop, hvor vi atter har nogle forpoststillin- 
ger i nogle skyttegrave, hvor fjendens kugler piber en del. Nogle er sårede og har fået et såkaldt »heimatsschuss«. Det er en ret bakket egn, og der har været kæmpet ikke så lidt, men endnu er der ikke kommet en egentlig afgørelse. Der er sikkert noget at vente. Granaternes hvinen og kuglernes hvislen er en jævnlig musik, men fortræd gør de ikke. Mad og drikke er der knapt med. Meget er der ellers ikke at fortælle - først når jeg atter er hjemme hos jer - og det glæder jeg mig dagligt til. Livet her er de fleste virkelig trætte af. Vi ligger stadig alarmberedte. $\mathrm{Og}$ i morgen har I jo så konfirmation. « [Bror Eriks konfirmation, JSS].

Suwalki, 1. april 1915: »Rigtige fægtninger har vi endnu ikke haft. I stilhed har vi trukket os tilbage til Suwalki i dag ved daggry. Bag os blev broerne sprængt, og huse - ja selv en stor køn kirke brændte. Det er selvfølgelig sket af strategiske grunde. Byen her er ret stor, og der bor endnu mange jøder her - ret anstændige folk. Jøderne har helligdag i dag - spiser syrnet brød osv., som deres skik er.

Augustow, påskelørdag 3. april 1915: »Kom til Augustow i går eftermiddag og ligger her $\mathrm{i}$ reserven og har det ret godt. Augustow er en by med 30.000 indbyggere, men ikke at sammenligne med byer, vi kender. Der er dog en del stenmurede huse, men ellers er der mest små træhuse. Nogle enkelte brolagte hovedveje går gennem den, men ellers er der mest mange små gyder og baggårde, hvor den største smuds og fattigdom holder til huse. Der er kun en lille del af befolkningen tilbage, mest jøder og så de mest fattige og krøblinger. Nøden er stor blandt dem - mange løber barfodede omkring og har knap laser på kroppen. Jøderne er mere velstående. Forretninger er der ingen af, men undertiden kan man dog få en jøde opsøgt, som har et eller andet at sælge. Der er to meget kønne kirker her - en russisk og en romersk katolsk."

Augustow, 4. april 1915: "Er endnu i Augustow, og her er stille og roligt, og jeg har været til feltgudstjeneste. Jeg har lige været $i$ byen for at forsøge at købe sukker og chokolade - alt er tomt - og næsten intet af få.«

9. april 1915: [Der er to postkort - et på tysk og et på dansk - hvis indhold næsten er det samme. Sandsynligvis fordi censuren har krævet at få oplyst, hvad Sigurd har skrevet på dansk, JSS]." Lebe jezt friedlich und gemytlich und had uns Frühlingswetter.«

10. april 1915: „Vi har eksercits og skansearbejde, når vi ikke hygger os i skyttegraven, hvor man dog kan lade os i ro.« 
11. april 1915: „Udenfor er alt gråt $i$ gråt, og det har silet ned hele dagen, så mange har holdt sig inden døre. Vi har været i denne stilling i en uge. Den ligger ca. $4 \mathrm{~km}$ øst for Augustow. Vi har gravet og bygget stillinger.[...] Men jeg må skrive mig ud af det, som er uforståeligt.«

14. april 1915: "Vi ligger stadig $i$ den samme egn. Russerne ligger ca. 600 meter borte i et skovbryn. Artilleriet har endnu ikke voldt os ubehageligheder, og geværilden er vi godt skærmet for. Endelig en dag med hilsner hjemmefra.«

16. april 1915: »Endelig i går fik jeg den store glæde at få 8 pakker og flere breve fra jer. Stegen fik jeg lige tid til at holde aftensmåltidet på. Det gav lyst og mod og styrke både til sjæl og legeme, så nu er jeg blevet let $\mathrm{i}$ kroppen og ikke føler det hele så tungt og trist.«

I skyttegraven ved Kalvarija, 19. april 1915: "Vi blev med bane transporteret over Suwalki til Walkowyski [nu Vilkaviskis, JSS]. En interessant rejse til en afveksling - overalt gennem egne, hvor kampen har raset hårdt, afbrændte byer, skyttegrave efter skyttegrave. Trådforhindringer og hist og her krigergrave. Fra Vilkaviskis marcherede vi om lørdagen til Marijampole, en ret tiltalende by efter forholdene her - kønne kirker og ikke så få teglstensbygninger. Vi er nu i skyttegraven ved Kalvarija. Det har været roligt med geværild, men artilleriet buldrer lidt.«

Kalvarija, 20. april 1915: "I går var der artillerikampe på begge sider af os, men i dag er det roligt. Geværild er der ingen af, og det kommer mig for, at vi på begge sider mest havde lyst til at gå sammen og drikke et venskabsbæger. Jeg talte lige med en kammerat fra Vestpreussen, og $i$ al spøg foreslog han at spadsere derover. Et russerhus her har i reglen en stor stue, hvori der står et åbent ildsted, bag hvilken der er en stor ovn. På ildstedet står der en del sodede lerpotter, der bruges til kogekar. Ovnen er vel egentlig til bagning, men har dog desuden en anden meget vigtig opgave. Oven på den er der ofte indrettet et leje. Der ligger så fatter og "matka « og så mange, der nu kan være og driver den af den lange kolde vinter. Påfaldende er også, at de anbringer små børn - ikke i en vugge, men i en kurv, der hænger og vipper på en stang, som er fastgjort ved en af loftsbjælkerne. Husene er næsten uden undtagelse bygget af træ, og væggene er tætnet med ler og mos.“

I skyttegravene ved Kalvarija, 25. april 1915: „Der er sådan en ro i stillingerne om dagen, men om natten er der også blevet skudt helt vanvittigt undertiden, mest fra russerne, der skyder mest ud i det blå, så man næsten ikke ved, hvad der foregår, og ingen vil bryde sit 
hoved med det. Vi ligger ellers godt her i stillingen og har ingen tab.«

I skyttegraven ved Kalvarija, 26. april 1915: „Kære alle! I dag ligger vi atter i strålende forårsvejr og nyder livet i ro her i skyttegraven. I aften skal vi atter afløses og kommer så tilbage og får forhåbentlig atter post en gang, og da kan vi jo sagtens. Det gode vejr, vi har haft på det sidste, har hjulpet os uhyre, så vi har virkelig alle befundet os så vel. Nætterne bliver korte og lyse. Det er en uhyre lettelse for vagttjenesten om natten. - I har vel sagtens hørt så meget om skyttegrave, at det næsten er overflødigt at skrive om dem - dog - jeg vil lige fortælle lidt om, hvordan vi har det. Vores skyttegrav ligger på en lille bakkeskråning, - udstyret med et par planker - nogle huler er gravet ind i baggrunden, hvor vi har vores egentlige opholdsrum, når vi ikke har vagter. Hver mand har sit skydeskår, og der er plads til tornyster, patroner, spade osv. På grund af fugtighed er gravene knap så dybe, at man kan gå oprejst der, hvad der jo er en fejl. På bakkeskråningen - en 500-600 meter foran os - ligger russerne i deres stillinger. Vi bemærker dem sjældent - kun om natten hører vi dem tydeligt, når de arbejder på deres trådforhindringer, som de har en 30-50 meter foran gravene. Også vi har trådforhindringer foran os, og sidste nat måtte vi i vor gruppe ud for at arbejde på dem. Om dagen er der i reglen ikke meget løs. Der står kun nogle enkelte poster, og ellers kan vi drive den af, som vi vil, når bare artilleriet vil lade os $i$ ro, hvad de heldigvis gør - kun skyder de fra begge sider oven over os. Når natten kommer, har vi så vores egentlige arbejde. Der bliver opstillet dobbeltposter og udsendt patrulje foran trådforhindringerne. Dernæst bliver gravene udbedret, og i reglen hentes der også mad. Artilleriet skyder sjældent om natten, men derimod falder der jævnligt nogle geværskud, eller et maskingevær skratter. Lyskastere afsøger med mellemrum terrænet. Lyskugler afskydes hist og her. Sådan forløber dag og nat, når der ikke er noget særligt løs, og der er da ikke megen fare ved det. Og vi har ikke en gang nogle sårede. I begyndelsen er det selvfølgelig lidt trangt at leve i disse huler, men man vænner sig hurtigt til det og finder også snart behag derved. Det er jo nu en gang krig, og man er tvungen ind i det, men søger dog alligevel at komme så godt som muligt igennem det. Lysten er kun ringe - også andre steder kan jeg forstå, - at man kunne finde sig i det. - Det var lige et par ord - alt vel ellers - håber også, at det står godt til hos jer. Mange gode hilsner fra jeres Sigurd. NB. Kunne godt bruge en god blyant og et stykke sæbe.« 


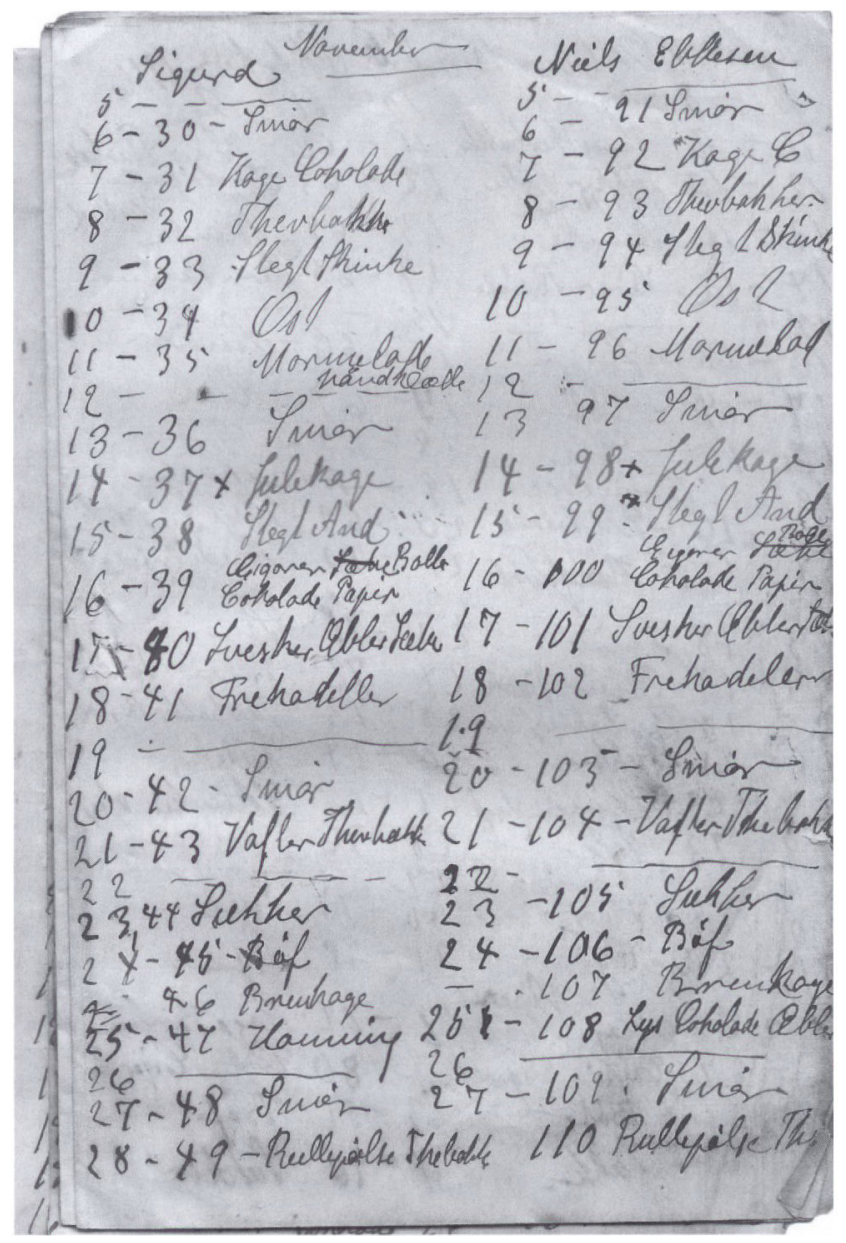

Sigurds mors oversigt over de pakker, som hun i november 1916 sendte til Sigurd og hans to år yngre bror, Niels Ebbesen Kloppenborg Skrumsager, der også var indkaldt.

30. april 1915: "Vi har haft det så uroligt. Den søde skyttegravsfred er nu forbi, men det kan snart blive godt igen. Gud har som hidtil holdt sin hånd over os og vil nok stadig stå os bi.«

1. maj 1915: "Vi er gået $i$ dækningsgraven og venter på et stormangreb - ja det har været stormfulde dage. Vi venter at skulle bryde op. Johansen er faldet, men Gud ske tak er jeg stadig sund. " [Johansen var søn af en lærer, uddannet som købmand og et par og tyve år, da han faldt ved fronten, skrev Sigurd $i$ brevet af 5. maj, JSS]. 
4. maj 1915: »Efter de stormfulde dage synes der nu atter at være kommet ro, dog suser sharpnellerne også om os nu i øjeblikket. Vi er fortsat på samme sted."

6. maj 1915: "Vi ligger endnu i de gamle stillinger - nogle steder i 100 meters afstand til russerne, og de lader os ingen ro. Overløbere kommer der også en del af - døde ligger omkring - det er en trist tid.«

6. maj 1915: »Vi kom $i$ aftes ud af skyttegraven og ligger $i$ dag $i$ reserven et par kilometer bag. Jeg håber at få lidt fred og ro til at nyde indholdet af de pakker, I har sendt."

8. maj 1915: "Blod og jern er luften her fyldt med. Vi ligger fortsat i samme stilling, hvor russerne stadig arbejder sig nærmere på. Flere af kompagnierne har haft større tab, men vi har haft held med os. Gud give, det snart må have en ende.«

9. maj 1915: »Vi står lige for igen at rykke ud i skyttegravene. De sidste dage af april og de første dage af maj var slemme. Vi har ligget i en uhyggelig ild, særligt den 29. april. Russerne har flere gange angrebet, men vores kompagni har været heldig, og vi har ikke været så slemt med. Vi holder stadig de samme grave, men russerne er enkelte steder nær - et sted kun 30 meter fra trådforhindringen, så der kan tales sammen. Håndgranater, miner og sådant kram bruges."

I skyttegraven ved Kalvarija, 11. maj 1915: "Når vi er i skyttegraven her, må vi enten være på lyttepatrulje eller stå på vagt hele natten - med opplantet bajonet. Her har vi mangen en gang ventet $i$ spænding på fjenden. Russerne brød igennem ved 4. kompagni, og 100 russere havde sat sig fast $i$ vores løbegrav bag dem, men med stor hårdhed atter blevet kastet ud af et reservekompagni, hvorved der faldt en mængde. De sibiriske tropper, vi her ligger over for, skulle være ret energiske. De har sorte huer. Endnu ligger der her flere døde russere ved stillingen. Mærkeligt, at Røde Kors ikke løser sådanne opgaver. Vores har da også kastet en seddel over til russerne, hvorpå de havde skrevet, at de skulle komme over til os - de ville ikke blive skudt. Svar er der ikke kommet, undtagen af og til et par håndgranater, som atter er blevet besvaret. Urolighederne begyndte egentlig fra vores side den 28. april, da vi skulle storme. Næste dag gik russerne på os."

12. maj 1915: „Vi ligger et par kilometer bag fronten. Der kommer mange forvildede kugler, så vi må finde fuld dækning. Der kom lige et rygte, at krigen næsten skulle være udbrudt med Italien, hvad der 
dog dæmper lidt på nogle, men det forvisser mig endnu mere om en såkaldt "Endgültigen Sieg." Ja - det er jo en skrækkelig tid for hele verden - diplomaterne driver deres spil og lader tropperne marchere. Fremmarchen i nord og syd er vi ganske uberørte af, og jeg kan ikke tænke, at det virkelig skal gå så slemt. Russernes magtesløshed ligger ubetinget i førelsen - folkene går blindt på - gang på gang under store tab - det ærgrer mig altid.«

Ved Kalvarija, 16. maj 1915: »Vi har fået lavet en rigtig god hule, hvor vi kan ligge en hel gruppe. Den har fået navnet »Villa Käthe«, navnet på vores gruppefører Milch's kone.[...] I går havde vi en ret oprørende og anstrengende dag i skyttegraven, hvor russerne angreb os og nemt kunne have overrumplet os, hvis de havde været under en god ledelse - men der brister det jo altid for dem. Førerne sidder i gravene og driver folkene frem, og de går blindt på, men der mangler jo samlingen i det hele, og så fører det jo ikke til noget uden tab. Det var et stormende øjeblik, så længe det stod på - granater og shrapneller suste fra begge sider, så det hele stod i rog og damp, men i spændingen ænser man ikke faren. For hvem, der kan forbinde handling med ønsker, er det jo let - ja kunne man bare det.«

Pinsen 1915: »Kære far, mor og søskende! Nu vil jeg fortælle lidt om, hvorledes vi har fordrevet pinsen. Vi har stadig haft herligt vejr de sidste dage. Pinselørdag tænkte jeg ofte på, hvordan vil pinsen dog blive under disse forhold, og mine tanker gled ofte hjem til jer og søgte at forestille mig, hvordan I havde det. Vi lå i skyttegraven og natten mellem lørdag og søndag arbejdede vi stærkt på en ny hule, og jeg var blandt andet også på lyttepatrulje. Månen skinnede, og luften var lind. Allerede kl. 2 var det omtrent lyst, og trods højtiden faldt der stadig skud fra vor side, men det stilnede dog snart af, efterhånden som de fleste kunne lægge sig til ro, og der kun blev nogle enkelte poster tilbage. Jeg havde nu svært ved at sove, da de små feltgrå bearbejdede mig så flittig, og enden blev da også, at jeg til sidst stod op og påbegyndte en lille renselsesfest. Solen skinnede varmt ned i graven til os, og jeg sad i nøgen figur og undersøgte tøjet fra top til tå. Bedst som jeg var i gang hermed, råber posten, der stod ved siden af mig, at nu har russerne plantet et par hvide faner på deres dækning - jeg sprang op og ser - ja minsandten[...] hænger min skjorte på en spade og vinker af alle kræfter, og de vinker igen. Hoved kommer frem ved hoved, og snart kan også vi vise os fri for dækningen, $o g$ vi råber til hinanden, og en af russerne tager en af deres faner 
og løber frem imod os - men - kammeraterne vil dog ikke følge ham, og han må snart løbe tilbage igen, dog vinker han stadig med fanen og viser sig så bevæget. Henrykkelsen varer en tid - det kunne selvfølgelig ikke blive ved, - men der faldt stadigvæk ingen skud den formiddag. Det var dog kun et forspil for, hvad der skete om eftermiddagen - det var næsten utroligt - da udveksledes der håndtryk, og næsten alle løb vi frie omkring - men derom senere. Om aftenen blev vi afløst af 4 . kompagni og måtte så arbejde på løbegravene, til det dagedes, og kom så sultne og trætte i vort reservekvarter her. Der måtte så soves, og jeg har lige vasket og tumlet mig frit her på græsset man bliver jo ellers så stiv og krum af de bøjede stillinger, vi stadig går i. Nu kalder spaden igen - modtag da mine bedste hilsner fra jeres Sigurd. Gud give os snart en god fred. Hilsner fra jeres Sigurd."

21. maj 1915: "Vi har meget skansearbejde og kommer sjældent $i$ ro - ellers alt vel.«

„Villa Käthe«, 25. maj 1915: »Vi har lige været ved at arbejde lidt på vores lejlighed - har fået bord og nogle bænke stillet op uden for vores hule og søgt at gøre os det lidt hyggeligt. I aften marcherer vi atter ud for at hilse på russerne - forhåbentlig lige så venligt som på pinsedag."

29. maj 1915: [Sigurds far sendte 29. maj et brev til Sigurd, som blev returneret til Bejstrupgård. Sikkert fordi Sigurd fik orlov mellem 26. og 28. maj og straks rejste hjem. Han havde orlov til 30. juni om aftenen, JSS].

Berlin Hovedbanegård, middag 28. juni 1915: »Rejsen er gået godt, og jeg har nu fået mine ærinder besørget.[...] Nu er jeg først klar over, hvor godt jeg har haft det hos jer derhjemme."

Königsberg, 29. juni 1915: "Alt her er ved det gamle. Krigen har sat sit alvorlige præg på det hele. Høsten tegner meget dårlig i egnene, vi er kommet igennem."

Eydtkuhnen, 29. juni 1915 om formiddagen: [Østpreussen på grænsen mellem Kaliningrad og Litauen, JSS]. "Krigen har hærget slemt her engang, og hvor ser det endnu afskyeligt ud.«

Vilkawiszki, 29. juni 1915: "Jeg har nu fået opsporet mit regiment, som ligger $15 \mathrm{~km}$ øst for Marijampoli. Der er en vældig færdsel her i byen, og der er efterhånden dukket en mængde jødeforretninger op i den, så der nu kan købes mange ting. Der er rejst en mindesten til ære for de faldne krigere.«

Marijampoli, middag 30. juni 1915: "Jeg er nu vej ud til mit regiment og har truffet flere sårede, som kommer fra lazaretter og skal ud til fronten igen. Har det efter omstændighederne godt." 
1. juli 1915: "Jeg er tilbage, og regimentet har lejet sig ind i en stor lade. $\mathrm{Nu}$ er der vist ro, men russerne har dog krudt endnu."

Zirmiskiai ca. 15 km øst for Marijampoli, 2. juli 1915: »Jeg er kommet godt tilbage. Det er ellers svært for mig at rejse herop anden gang - det så så sort ud, alt var en elendighed. Det er svært at forliges med krigen. Kammeraterne ville selvfølgelig høre nyt - navnlig om fred, men derom havde jeg desværre intet. Vi delte så smørret og vinen, og lod os det smage godt. Alle mine nærmeste kammerater er her endnu. Fluer er der et mylder af, så man næsten ikke kan være i fred for dem."

Zirmiskiai, 3. juli 1915: „Egnen her er næsten ikke ødelagt. Befolkningen og dyrene er borte. Håber, at jeg får lov til at fejre min fødselsdag her.«

Ilskani ved Marijampoli, 6. juli 1915: »I dag er det så min fødselsdag - har et stille varmt sommervejr - ligger stadig i vort gamle kvarter og mærker ikke meget til fjendtlighederne. Fluerne er nu den værste plage. Vi har set en spion blive ført til sit sidste hvilested - dommeren oplæste dommen for ham - en salve lød, og det var forbi men indtryk gjorde det vist på alle. Vi ved ikke, hvor længe vi bliver her.«

Igliskeliai, 11. juli 1915: [Igliskeliai ligger $8 \mathrm{~km}$ øst for Marijampoli, JSSJ. "Læste i Dannevirke om, at Jens Skøttegård fra Abkær skulle være faldet samt Chr. Møller fra Harreslev - hvor er det dog stadigvæk mange, der rives bort. Det er en tragisk tid på mange måder, og man kan nemt forfalde til tungsindighed. Her er stadigvæk stille og roligt. Hejmdal kommer næsten aldrig mere, men derimod kommer Modersmålet dagligt."

Kurland, 16. juli 1915: [Stedsangivelsen Kurland $i$ denne og følgende 4 breve er ikke korrekt. Kurland ligger i det nuværende nordvestlige Letland, og Sigurd befinder sig fortsat $i$ det nuværende Litauen JSS]. "Der er ikke meget at lave. Vi ligger fortsat $i$ en stor lade. Mangen en gang har jeg tit længtes efter at have en god bog at underholde mig med.«

Kurland, 18. juli 1915: "I forgårs aften kom der så pludselig befaling om at gøre os marchberedte, og næste morgen gik det så løs. Hvorhen vidste vi selvfølgelig ikke, men det gik nordpå, følte vi. Langsomt sneglede vi os så frem gennem gode og kønne egne med store kraftige skove. Omsider nåede vi så Marijampoli-Kaunas vejen og fortsatte så efter Kaunas. Vi er nu tæt på fronten.«

Kurland, 24. juli 1915: »Den 18. juli kom vi så i skyttegravene, og 
det blev sagt, at vi skulle storme den følgende morgen, men på grund af regnvejr blev det udsat, og sådan gik det dag for dag indtil den 20. om aftenen. Da blev vi i 1 . bataljon afløst af 2 . bataljon, og vi kom i reserven - og de skulle storme. Efter frygtelig artilleribeskydning blev gravene stormet uden modstand - alle var flygtet, og snart kunne artilleri og reserver rykke frem over det hele. Om formiddagen kom vores kompagni i spidsen, og vi fik til opgave at undersøge nogle skovbryn, hvad der gik let - alle flygtede for os, men ved middagstid mødte vi dog modstand og opdagede, at vi lå over for en russisk hovedstilling. Vi gravede os ned - hver mand i sit hul, og vi fik befaling om at blive liggende. Så vidt jeg kan forstå, ligger vi nu i en kile ind mod Kaunas ved fronten mod syd. Nu er vi blevet afløst og ligger i reserven.«

Kurland, 25. juli 1915: "Her i dag har vi atter haft en fægtning, men er allerede blevet afløst. Vi kommer nu nok på en ny transport.«

Kurland, 26. juli 1915: »I går havde vi atter en lille fægtning - og tog ved hjælp af artilleri og miner en stærk skyttegrav i en skovkant. Vi havde ikke videre tab. Sagen var nemlig godt forberedt. Det går jo voldsomt fremad her, og ens stilling her kan jo være blandet nok, men når man tænker lidt ligegyldigt, kan man finde sig i det, og det er man nødt til. De åbne fægtninger synes ikke at være så farlige som den stilling, vi havde ved Kalvarija.«

Kaunas, 30. juli 1915: „Er nu kommer i kvarter igen - lå i går i fægtning det meste af dagen - er sund og rask. Gud være med os alle."

Kaunas, 31. juli 1915: "Den sidste fægtning havde vi den 29. juli, og det var også den værste, vi havde den dag - 11 mand tabt $i$ vor kamp. Vi begyndte ved solopgang og nåede straks ind på 700 meters afstand fra den russiske stilling, og der måtte vi så blive liggende til kl. 1. Da stormede vi under kraftig støtte fra vort artilleri. Russerne overgav sig straks. I store klynger kom de frem og blev drevet sammen og transporteret tilbage. Derved var det værste overstået, og der blev ikke gået meget mere frem. Vi var da tæt inde på Kaunas og kunne blive beskudt med artilleri fra forterne, hvad der er mest ubehageligt ved stillingen her. Vores tøj er kommet til at se medtaget ud efter fægtningerne. «

Kaunas, 2. august 1915: "Sidste nat blev vi kommanderet ud på lyttepoststilling, og vi drev ganske fredeligt omkring 500 meter foran vores stilling. Der skete intet."

$10 \mathrm{~km}$ fra Kaunas, 3. august 1915: »I dag ligger vi i den russiske skyttegrav, som vi tog den 29. juli. De russiske skyttegrave er mange gange 
bedre end vores, og det $\mathrm{i}$ alle henseender, men de er jo også blevet anlagt i ro og fred. Gevær og shrapnel-ild er man næsten fuldstændig skærmet for i dem. De er meget rummelige og udstyret med bord og bænke. Desuden er der en mængde huler med gode lejer - væggene er beklædt med strå, og enkelte har været pyntet med blomster og helgenbilleder. Trods det, er de løbet fra det. Den egentlige front ligger 1.000 meter forude. Russerne har lige sendt en ballon op med deres artilleriiagttager. Det er en mærkelig kolos, og den hænger og svinger rundt, og man skulle undres over, at den ikke straks blev skudt ned af os, men vort artilleri er vel bange for at forråde deres egen stilling.«

Kurland, 7. august 1915: »I går aftes gik vi atter frem. Forhåbentlig bliver vi snart afløst - vi er næsten sorte som negre. Vi er ikke blevet vasket den sidste uge."

Kurland, 9. august 1915: "Vi er stadig foran Kaunas, som daglig bombarderes. Lå i går $\mathrm{i}$ artilleriild og forsøgte at gå frem. Har det godt efter omstændighederne, men har ellers fået nok af det hele de sidste dage - dem glemmer jeg aldrig.«

Syd for Kaunas, 11. august 1915: "I går aftes tog vi igen med stor lethed en meget stor russisk stilling og fik nogle fanger, men kun få. De var løbet $\mathrm{i}$ tide. Vand er det knapt med. Brøndene er ødelagte som alt andet.«

13. august 1915: „Stillingen den samme. I går slog en granat ned lige foran min sidemand og mig, så vi blev helt tildænget med jord, men ellers slap vi lykkeligt fra det. Også i øjeblikket bombarderes vi stærkt, og vi må af og til søge ned i vores hule og søge dækning. Vi har nu ligget så længe i denne kanonade, at vi tager koldblodigt på det - det bliver til en hel vane."

Foran Kaunas, 15. august 1915: "I går gik vi atter stærkt frem. Fægtningerne synes at være meget hårdnakkede i går, og forskellige steder måtte vi løbe tilbage. Natten igennem hørtes stadig råb og skrig fra dem, der gik frem til storm. Så vidt jeg kunne høre, prøvede russerne også på at gå frem adskillige gange. Det siges, at et fort er taget og et par kompagnier har været inde $\mathrm{i}$ et eller andet. Vi har nu ligget i 3 dage i forreste linje, hver mand i hver sit lille hul."

Syd for Kaunas, 16. august 1915: "Vi ligger i en forladt russisk skyttegrav. Kanonaden er vedvarende stærkere, og den brager næsten både nat og dag, men det synes ikke at have de store virkninger.«

Syd for Kaunas, 18. august 1915: »I går trængte vi ind i forsvarsværkerne i Kaunas og ligger nu i et virvar af skyttegrave og trådfor- 
hindringer, krat og kløfter, så det er ikke så nemt at finde sig tilrette."

16 km øst for Kaunas, 21. august 1915: "Kaunas er nu falden måske. Den 19. august marcherede vores bataljon med musik i spidsen gennem den sydlige del af det faldne fæstningsværk og kønne anlæg, som nu bærer spor af krigens hærgninger. Den 18. lå vi i fort 4 og den 19. i fort 6, og derpå gik vi østpå og fik en forpost i Njemen. I går morges gik det videre østpå. Russerne viger stadig, men har dog hist og her punkter, hvor de holder os op en tid."

Omtrent 40-50 km øst for Kaunas, 24. august 1915: "Vi marcherer stadig østpå uden at have rigtige træfninger med russerne. Det går stadig i zigzag gennem dalene. Befolkningen er væk.«

26. august 1915: »Vi er endnu på vej østpå, og vi vil snart nå Vilnius. «

28. august 1915: »Vi er nu $40 \mathrm{~km}$ fra Vilnius og tæet ved en flod. Vi har flyttet lidt rundt uden at kunne komme frem for russere.«

Omkring $40 \mathrm{~km}$ vest for Vilnius, 30 . august 1915: "Hen imod aften stormede vi så og trængte derpå et par kilometer frem og tog nogle fanger. Vort kompagni havde et tab på 4 døde og 4 sårede (4. kompagni havde derimod 20 døde og sårede). Der er et ganske vildt terræn her og ikke nemt at opklare, og russerne yder tilmed hårdnakket modstand, så vi kommer ikke meget fremad. Just behageligt er det ikke at drive rundt $\mathrm{i}$ dette vildnis, hvor man ofte ikke ved, hvilken side af fronten man er på. Vort mål er Vilnius, og vi er ved en flod med mange søer. På et kort kan I nok se det."

1. september 1915: „Vi er i en af Ruslands fyrreskove mellem Vilnius og Memel « [Klaipeda, JSS]. »Jeg ligger på lyttepost og skriver. Fremmarchen er standset, og vi graver skyttegrave. Det er svært at sige, om russerne vil lade os komme frem, eller om de endog vil forsøge en ny offensiv, - men de har vel lidt så mange tab, at de endnu må gå tilbage.«

Vistnok lidt ost for Ganuschichki, 2. september 1915: "De sidste dage har været ret regnfulde, noget vi ellers har været forskånet for her i området. Landskabet er helt idyllisk - bakker, søer og skove.«

Drabuzininkai, 4. september 1915: "Vi har arbejdet med at bygge huler. Gud ved, om vi får brug for dem.«

Nær Spindzius, 6. september 1915: "Rykkede igen ud i første stilling og har haft travlt med at udbygge huler - skydeskår m.v. Russerne ligger endnu nogle kilomenter borte, så vi har egentlig gode og rolige dage. Tiden skrider fremad, så vi dog snart må nærme os enden på al denne ufred.«

Drabuzininkai, 8. september 1915: „Vi befæstede vores stillinger 
stadig mere og mere, men har det ellers roligt her. Endnu kniber det med at skaffe forplejninger frem."

Spindzius, 10. september 1915: »Russerne ligger 3-4 km herfra og lader os i ro. Stillingen er altså her ganske enestående, og vi er glade, så længe vi får lov til at blive her. Men mange længes efter lidt sul, og enkelte forsøgte så jagten på nogle omstrejfende får, hvoraf der blev nedlagt nogle stykker. En af dem hænger nu ved vores skyttegrav til fri afbenyttelse. Jeg gjorde forsøg med at lave lidt bøf, og det faldt helt godt ud.«

18. september 1915: "Efter at vi havde stormet den 16., er vi på fremmarch mod Vilnius. Vi gør i øjeblikket holdt ved et jernbaneknudepunkt N... F.... Alt vel efter omstændighederne.«

20. september 1915: »I forgårs passerede vi Vilnius og er nu på vej sydøst og har tilbagelagt ca. 25 kilometer. Forplejningen er det dårligt med.«

Nordvest for Crekmjany?, 22. september 1915: „Vi er endnu på fremmarch, men det går kun småt frem. Russerne yder synlig hård modstand. Det kniber med at få fødevarer frem, så brødet er nu blevet en lækkerbid.«

$20 \mathrm{~km}$ ost for Crekmjany, 24. september 1915: "Samtalerne går i stå - der tales ikke meget, tilmed er alle sultne, og man skal være om sig for at få stillet appetitten."

Crekmjany, 28. september 1915: "Vores frontafsnit strækker sig gennem en tæt skov, hvad der kan være yderst ubehageligt, da russerne har været ret dristige og undertiden er kommet enkeltvis og tæt ind på stillingen. Følgen har været, at der knaldes hele tiden fra begge sider, så der nemt kan ske ubehagelige overraskelser.«

29. september 1915: "Vi blev pludselig afløst fra de første stillinger og trukket tilbage til et kvarter på et stort gods. Befolkningen er flygtet, og vi finder gods og vogne gemt i skovene."

I kvarter ca. 20 km øst for Crekmjany, 3. oktober 1915: „Russerne har lavet et gennembrud lidt til venstre for os i natten mellem den 29. og 30. september. Vi mistede flere hundrede, som døde, blev sårede eller taget til fange. Russerne har også haft umådelige tab og blev atter kastet tilbage. Vi var ude, fordi vi ventede et nyt angreb, men det blev der intet af. Endnu lå der en del døde og et par sårede omkring - vore og russere mellem hinanden. Det går over ens forstand, når man ser sådanne billeder. Nu må jeg slutte - vi marcherer nu atter ud i de forreste stillinger - forhåbentlig vender vi snart tilbage og får bedre dage.« 
10. oktober 1915: "I går var vi på en længere march mod nord og ligger i dag i ro. Jeg har været stærkt optaget og derfor ikke kunnet skrive siden den 7. oktober."

Smorgon, 11. oktober 1915: [Nu Smarhon, 60-70 km øst for Vilnius, JSS]. "Vi ligger 6-7 km bag fronten og har det ret roligt. Begivenhederne ved Vestfronten har jo vakt en del interesse for os i den sidste tid - men ak - hvad bliver det til - endnu synes det mig så underlig fjernt. Der har sikkert været umådelig store tab over al den tid, og mange triste budskaber må der modtages. Så jeg kan godt forstå, at I går i spænding, eftersom I slet ikke hører fra mig - men det må ligge i, at der er spærret. - Jeg er Gud ske lov kommet godt gennem alt til det her og er endnu sund og rask."

[Sigurd blev $i$ området ved Smorgon $i$ knap 14 måneder, indtil han blev forflyttet til Vestfronten $i$ december 1916. Smorgon ligger $i$ det nuværende Hviderusland. Ved at skimme de mange breve og brevkort fra oktober 1915 og indtil Sigurd blev forflyttet til Vestfronten, er der selvfølgelig mange hændelser. Her næunes nogle fä, JSS].

I skyttegraven ved Smorgon, 20. marts 1916: "Kære far og mor! I går, da jeg var ude for at søge vand, traf jeg helt tilfældigt en landsmand - Hellesø fra Jels. Han er ved lyskasterne her og blev selvfølgelig meget glad ved at træffe en landsmand. Han er urmager og har været hos Markussen i Rødding. Blandt andet er der nu for alvor blevet liv her på fronten, men vi er sluppet godt igennem det hele her. I går var det en ganske forrykt dag - vort artilleri skød meget af tiden og undertiden med største heftighed - samtidig satte infanteriet tre gange ind med geværild - lyskugler sted til vejrs, og vi skulle råbe HURRA - som vanvittige skabte vi os - og jeg ved ikke, hvad russerne tænkte - men de var meget rolige. Vi får ikke megen ro i disse dage. Gud står os stadig bi - her. Bedste hilsner jeres Sigurd.«

26. marts 1916: »Nord for os står der dog jævnligt kampe - $i$ aftes meget heftig."

Smorgon, 1. april 1916: "Luften har et par dage været så klar, at vi rigtig har kunnet iagttage de russiske stillinger - den ene bag den anden. Artilleriet lod os dog i ro. Russerne har sikkert trukket det bort her en tid. Flyverne har været i stærk virksomhed, og i går havde russerne ikke mindre end 5 balloner oppe her i egnen.«

Smorgon, 2. april 1916: "Det er ret roligt i dag - kun en underofficer - en skolelærer har stået og knaldet efter russerne - det er nu hans lyst - hvad der ellers ikke gør os tilværelsen mere behagelig. I en 
kikkert kan man ellers tydeligt iagttage russerne - der vasker deres tøj, soler sig osv. i dag. De længes også sikkert efter freden som os. Ærgerligt at der gives sådanne fredsforstyrrere.«

Smorgon, 21. juni 1916: »Billedet viser vores kompagnis musikkorps. Instrumenterne vil vist være jer fremmede, men vi har nu været henvist til dem alene. Vi finder dem meget morsomme, når bare de kommer $\mathrm{i}$ talentfulde hænder.

II juni 1916 foretog et par bataljoner et stormlob mod russiske tropper og vandt nogle sejre og besatte nogle russiske skyttegrave. De to bataljoner fik lykønskninger og ol og rom sendt fra Hindenburgs højre hånd, Ludendorff. Rommen var ankommet den 18. juni og Sigurd skriver, JSS]:

»Mange er nu kommet i løftet stemning - jo det er tilstande - måtte bedre tider snart oprinde.«

Smorgon, 10. juli 1916: "Vi kan ikke fortælle alt. Gasangrebet, som russerne har skrevet om, er rigtigt nok, og vi var også delagtige i det, men det blev ikke omtalt fra vores side, vel på grund af det mindre gunstige udfald, og det var ikke skadeligt på grund af ugunstige vejrforhold.«

Neu Westend, Berlin, 31. august 1916: »Her går der nu en mængde rygter om nye krigserklæringer. Med Rumænien og Italien har det nok sin rigtighed, men i dag fortælles der endog, at Danmark også skulle have erklæret os krig. Det er selvfølgelig opspind.“

[Italien gik allerede $i$ maj 1916 ind $i$ krigen mod Tyskland og ØstrigUngarn på Ententemagternes side. Sigurd var på en kort orlov $i$ september måned - hvor længe og hvor er ikke næunt. Orloven er nævnt $i$ brev fra 9. og 10. oktober, JSS].

Smorgon, 5. oktober 1916: »I dag blev alle elsasserne fra hele regimentet kaldt sammen, og majoren lod dem sige nogle alvorsord $\mathrm{i}$ anledning af, at nogle have forduftet sig. [Befolkningen $i$ Elsass-Lothringen/Alsace-Lorraine blev indlemmet $i$ Tyskland $i$ 1870-71 efter det franske nederlag $i$ den tysk-franske krig. Deres situation mindede derfor meget om de dansksindede sønderjyders, JSSI. Hvor meget det hjælper, er vel nok et spørgsmål. Det synes snart, som de deraf holder mere sammen. Russernes udlevering af dem til Frankrig er selvfølgelig en slem faktor. Der hersker selvfølgelig stor forargelse over slynglerne [...]«.

Smorgon, 22. oktober 1916: »Kære far, mor og søskende! Så svandt endnu en uge - atter er det søndag. Selv her i stillingen har vi en følelse af, at der er festdag. Alle arbejdere hviler, kun de enkelte dagsposter står, men ellers er det tomt i gravene - alle har søgt ind i deres 
huler til ro og fred, og så kan de udenfor skyde og gøre, hvad de vil. Det er endnu eftermiddag, og jeg sidder her og skriver, mens alle kammeraterne ligger på deres brikse og blunder. I formiddags var jeg til feltgudstjeneste - ja det gik sådan til. I aftes kom der befaling, at der fra hver gruppe skulle en mand til gudstjeneste. Som sædvanlig var der ingen, der frivilligt havde lyst at være med, men én skulle der jo med. Det var jo tjeneste, og så trak vi lod om det, og loddet faldt på mig. Jeg var dog helt glad ved det, da man dog fik lidt bevægelse og kom lidt ud og se sig lidt om en gang. Vi måtte marchere til en lille by Sadsoni [ $\mathrm{nu}$ Soly, $10 \mathrm{~km}$ vest for Smorgon, JSS] - en god times gang. Herude på en mark i læ ind til en skov var der lavet en lille talerstol, om hvilken vi så tog opstilling i hesteskoform. Efterhånden som officererne indfandt sig, blev der gjort honnør, og det går jo nøje til med det. Officererne samlede sig inde i midten, og endelig kom divisionspræsten og optrådte i al sin værdighed, udklædt i en grå uniform, bærende et stort sølvkors på brystet. Der synges et par vers, og et lille orkester ledsagede. Efter oplæsningen af en lille tekst følger så en lille prædiken, og altid er der meget patriotisk indvævet. Da det i dag var kejserindens fødselsdag, dvælede præsten især ved hende og kejserhuset, der nu med os bærer krigens tunge savn i det tredje år. Mod slutningen sagde præsten: "Det går nu på liv og død «, og endte så med nogle betragtninger om dødsforagt. Det kunne jo være meget godt, men folk synes kun at føle sig lidt traurige til at høre derpå. Det er, som om sådan noget dårligt kan trives under de militæriske former. Efter prædiken fulgte en kort bøn og en salme, og vi skiltes hver til sit. Jeg traf Hans Petersen, som før var ved kompagniet. Han var sammen med en Mathiasen fra Læk, som jeg også hilste på - han talte også dansk og sagde, at det gjorde alle på hans hjemegn. Nu ønsker jeg jer en god søndag. Og alle får så den bedste hilsen, jeres Sigurd."

Smorgon, 5. november 1916: "Det sidste næsten overraskende nyt, som vi har fået, er proklamationen om Polen til kongerige. Hvem kongen er, har jeg endnu ikke fået fat på, men det har jo også mindre at sige, man kan jo tænke sig til det. Bevæggrunde til skridtet kan man finde nok af. - Hvordan polakkerne vil tage det, vil tiden vise. Hvis det dog bare kunne blive et indledende skridt til den kære gode FRED. Vort nabokompagni havde i dag den molør [ulykke, JSS], at en russisk granat slog ned $i$ en hule og sårede ni mand. Ellers har vi almindelig ro. Ungdomstiden, der kunne være blevet så dejlig, hvor 
ødsles og spildes den ikke hen. Udviklingen går på mange måder i stå. Hvad krigen dog bringer med sig. Der er så meget, som er tragisk - og man magter så lidt.«

\section{Ved Vestfronten}

På rejse og ankommet til Belgien, 9. december 1916: "Rusland har vi nu forladt. Den 4-12-1916 rejste vi over Vilnius og til grænsestationen Kalins i lukkede godsvogne og gennemgik der en grundig desinficering og aflusning. Om morgenen den 7. december kom vi med et nyt transporttog med 3 . klasses vogne, og så gik turen videre ned midt gennem Tyskland - en helt interessant rejse. Den 8 . december passerede vi den belgiske grænse, og nu fik vi en meget køn rejse ind gennem Belgien over Liège - Bryssel, og nu er vi så her i L. - [navnet er ikke skrevet, sandsynligvis på grund af forbud, men byen er Lille, JSSI. Hvilken himmelvid forskel der dog er på alle måder - her og så i Rusland. Man må virkelig beundre det høje kulturtrin, som alt her står på. Hvad rejsen gælder, er mig ubekendt.«

L.... 10. december 1916: [Lille $i$ Frankrig, JSS, ] »Byen L.... er en pæn by med prægtige bygninger og kønne anlæg. Der er noget sirligt og fikst ved det hele, og der er mange kvinder. Befolkningen er i højeste grad proper og dannet og forstår at klæde sig. Man er her med på moden helt igennem. Forretningslivet er selvfølgeligt ret indskrænket, men man kan dog få mange ting, men ofte til fabelagtige priser (1 pund smør til $10 \mathrm{fr} ., 1$ pund flæsk til $10 \mathrm{fr}$. osv.) Alligevel synes befolkningen at stå sig nogenlunde igennem. Ude fra fronten hører man kanonernes torden, og jeg tænkte så på kammeraterne. Nu nærmer vi os julen, men man føler det kun så lidt.«

16. december 1916: "Så forlod vi i går morges H. ved L. og marcherede mod sydvest og ligger nu $\mathrm{i}$ en by $\mathrm{S}$. øst for L. B. Vi ligger nok som en eller anden reserve. Landskabet her er ganske fladt - ingen skove - lidt hegn - hyppige meget høje popler eller linde langs de meget gode veje - byerne ligger meget tæt, mange bondehuse er ofte meget statelige - altid tegldækket. Jordbunden er fed leret - alt bærer præg af stor frodighed. Ind mod fronten er alt skudt i grus, og der ligger det hele hen $i$ et vildnis. Her har vi jo englændere over for os. De er meget dygtigere og mere behændige i krigsførelse ved fronten. Især er de godt beslået med artilleri og har et godt flyvevæsen.[...] 
Til nu er alt forløbet meget roligt, og vi begynder at leve os ind $i$ forholdene.«

17. december 1916: „Over alt møder man krigens hærgning. Man ser, at folkene har rømmet det hele i hast - redskaberne står ofte, som om man er løbet fra dem. På en mark så jeg tre selvbindere stå på rad, som man kunne havde spændt for - nu næsten helt tilgroede og ødelagte osv. Vi passerede også en større by Herlies? [mellem Lille og Lens, JSSI, der så ud til at have været en prægtig by, men nu var alt ruiner. Selv den store kirke var der næsten ikke sten på sten. Også kirkegården var gennempløjet af granater.«

22. december 1916: "Her ved fronten er det alligevel en hel del mere uroligt end vi er vant til, og fra alle sider hører vi også, at englænderne er de mest hårdnakkede. Ellers er det lutter folk fra Bayern, som vi her ligger sammen med. Større venskab kan man jo ikke sige, der hersker iblandt os - tværtimod. Jeg har fået det indtryk af dem, at de uhyre let bliver gale $\mathrm{i}$ hovedet, og så bander de meget kraftigt for øvrigt volder det endog lidt vanskeligheder med at forstå dem fuldt ud med det samme.«

5. januar 1917: »I går forlod vi L, hvor vi har været siden den 15. december og marcherede en halv snes kilometer sydpå og ligger nu i reserven. Vi vil snart komme i stillingen syd for kanalen. Det bliver tungere og tungere med denne utålelige og ubegribelige krig."

Le Bassée, 14. januar 1917: „Vi ligger til venstre for kanalen meget tæt på englænderne. De fleste steder er der kun 20-30 meter mellem os og nogle steder meget mindre. Nogle rigtige skyttegrave er der ikke - det meste er skudt i stykker eller sunket sammen, så der kun er en mudderrende. Første aften, vi kom herind, var vi ved at opgive det hele - mudderet gik til langt op over knæene. Heldigvis havde vi forinden beviklet benene fra øverst til nederst med gamle pjalter, og hvad vi kunne få fat $\mathbf{i}$. Til alt held er der da nogle få tørre opholdsrum - minegange.«

Berklau, 19. januar 1917: [mellem Lille og Arras, JSS] »Til stort held var englænderne meget fredelige og gjorde ikke meget, når vi bare lod dem i ro. Artilleriet var heller ikke så slemt for os i første linje. En stor hjælp var det, at vi havde så mange bombesikre minegange at søge dækning i. Vi har kun haft en enkelt dræbt i de sidste 10 dage. Jeg vil gerne indrømme, at vi var ved at gå fra snøvsen de første dage og gjorde os alle mulige tanker og sagde til os selv, at vi lige så godt kunne være gadefejere et andet sted. I hvert fald er jeg grundigt træt 
af det hele og må jo gang på gang sige mig, at sådan kan det ikke gå videre. Jeg vil ikke udtale mig mere, men tror kun ikke, at man her tankeløst driver med, men ved også, at man kun magter lidt - men alligevel vil jeg forsikre, at jeg ikke vil miste modet.«

29. januar 1917: »I dag går det løs.«

N. ved Lens, 31. januar 1917: "Strabadserne er ikke det, der piner men det ubegribelige målløse i det hele og tit det spørgsmål, om det egentlig er det rigtige og nødvendige osv. I vil jo let forstå det. Der kan komme øjeblikke, hvor man synes, at det hele kan være ligegyldigt, og da er det hele let, og man kan spøge og være i humør. Dog er den letteste vej ikke den rigtige, føler jeg godt. Med alle disse grublerier kommer man selv til kort - sit sted, hvor man går hen med dem og finder fred - så er menneskers magt og vilje jo dog kun lille og svag. Aldrig vil jeg derfor blive forknyt, om det så ser nok så sort ud, men håber på bedre tider. Ja - lad os alle det - være uforknytte og ved godt mod.«

Lens, 2. februar 1917: "Jeg kom i aftes i stilling, men endnu i reserven i tredje linje. Alt er godt udbygget. Undergrunden kalk, der egner sig fortrinligt til anlæg af skyttegrave. Den her usædvanlige vinter holder ved til vores store glæde.«

Lens, 14. februar 1917: "Blev afløst i forgårs, og kompagniet gik i hvilestilling i N, hvor vi før har ligget. Vi - henimod 6 mand og en underofficer - fik ordre til at melde os ved armeringsbataljonen her i Lens for at hjælpe dem nogle dage. Det kan være lige så godt som det andet, og mange ville endog være meget glade ved det, da Lens jo er en stor by, og den derfor er en hel del "rehiels" ["fristelser m.v." JSS], som tyskerne siger. Vi har nu endelig fået os nogenlunde indkvarteret. Endnu har ingen forlangt noget af os, og det er vi selvfølgelig ikke kede af. - Det er mærkelige forhold at leve under. Trods det, at artilleriet daglig skyder herind, bor civilisterne endnu stadig her. Der er mange faldne blandt dem, og de må se på, at deres huse dag for dag bliver mere og mere ødelagte. Den store fare er de dem nok ikke bevidst, for ellers ville de drage bort - alle bor de i kældrene.«

Lens, 15. februar 1917: "Det har truffet sig sådan, at den armeringsbataljon, som vi blev tildelt, netop er den, som sidste efterår lavede skyttegravsanlæggene inde ved Arnum og Skærbæk. Jeg har selvfølgelig spurgt dem ud om, hvordan de havde været tilfredse og måtte så høre, hvor utilfredse de havde været med alt. Befolkningen var fjendtlige, alt tarveligt osv. - ja, de påstod endog, at folkene var dov- 
ne - nå - det hele er jo ikke værd at høre på - men det morede mig dog at høre deres dom - men le måtte jeg især, da de fortalte, at folkene spærrede alle deres unge piger ind - de lod dem slet ikke se [...].«

Lens, 16. februar 1917: "I går skulle der her på egnen være blevet skudt fire engelske flyvere ned. Selv har jeg dog kun set én flyverkamp. Det var spændende at se på - lige som høge suser de efter hinanden - englænderne er i tal langt de overlegne - er frække og koldblodige og aner ikke meget, når de skyder på dem. Vore ser man kun lidt, og de synes ikke at være så mange, men de er uhyre behændige og snedige. - Det er jo tunge tider, og det er ikke til at komme uden om.«

Lens, 17. februar 1917: "I går var det en slem dag, da englænderne skød meget med svært skyts, og da holder kældrene, som vi ellers søger ned $i$, ingenting. Bombesikre rum findes der kun få af - da er det snart bedre i skyttegravene, hvor vi har skakterne. Værst er det for de udækkede civile - koner, børn og gamle folk - de må sandelig døje meget, og man ser det på dem, at de lever i jammer og elendighed.«

Lens, 21. februar 1917: »Til venstre for os forsøgte vore forleden at trænge ind i de engelske stillinger, men det lykkedes dog ikke. Overalt på fronten forsøger begge parter at gøre sådanne omklamringsforsøg - mest er det frivillige patruljer. Vi er her det samme for englænderne, som russerne var for os $\mathrm{i}$ øst. Til trods for den livlige beskydning har vi dog næsten ingen tab.«

Acheville, 27. februar 1917: [Syd for Lens, JSS]. „Ved L. B. Iførste linje ved fronten, JSS] kunne vi jo tale med englænderne, men det var der nu ingen tale om, og der syntes tværtimod at herske en uhyre gensidig forbitrelse, og det var for mig det mest ubehagelige under de urolige forhold. - Hvad englænderne ellers formøbler af »muvilian « er ganske enestående. [Muvilian er et slangudtryk for ammunition, JSS]. Nat og dag lægger de både fronten og tilførselsvejene under en jævnlig ild. Store resultater har de vel næppe dermed, men det er meget foruroligende. På vores side synes det næsten at blive mere og mere sparsomt med muvilian."

Acheville, 1. marts 1917: "Englænderne skal have gjort mange hårdnakkede angreb og opnået små resultater. Gas brugte de også, og vi var i den anledning alarmeret, men kom dog atter til ro. I dag har vi været til badning og aflusning $i$ et gammelt bryggeri. Lusene 
er nu her lige så slemme som $\mathrm{i}$ Rusland. Vi er virkelig meget mere beskidte her end før i Rusland."

Vimy, den 3., 4. og 5. marts 1917: [Mellem Lens og Arras, JSS]. „Vi ligger nu 30-50 meter fra englænderne. Englænderne begravede deres døde fra sidste gasangreb."

Vimy, 6. marts 1917: »Efter alt at dømme nærmer vi os vist stærkt en stor offensiv. Flyvervirksomheden er her undertiden ganske enorm. For øjeblikket (jeg har nemlig vagt) hænger der ikke mindre end 21 over os - deriblandt en flok på 16 styk. Vores lader sig næsten ikke se - kun i udkanten dukker der et par kampflyvere op, og de skal straks have hentet tre englændere ned. I kamp er vores vist dog de overlegne."

Vimy, 9. marts 1917: "Ja, det er en omvendt tilværelse - dette muldvarpeliv og natmandsliv. Man ser ud som et svin - kan jo aldrig vaske sig - det er et hundeliv - men svært at komme udenom, selv om man vil være nok så snedig."

Acheville, 21. marts 1917: „I går meldte jeg mig syg. Jeg har følt mig lidt sløj den sidste uges tid. Er nu i reserven.«

Acheville, 23. marts 1917: »Er ved at være udhvilet. Driver tiden hen og får et par aspirintabletter.«

Krigslazaret nr. 23 i Ath, 31. marts 1917: [Ath ligger lidt nord for Mons og næsten midt mellem Lille i Frankrig og Bryssel $i$ Belgien - ca. 60 $\mathrm{km}$ fra fronten $i$ Vimy $i$ Frankrig. Det var her, Hans Lausten-Thomsen var læge. Sigurd blev forst overflyttet til denne læges sygesal $i$ Mittelschule natten mellem den 7.og 8. maj, men da havde han allerede været på lazaret nr. 23 i Ath siden den 30. marts, dog sandsynligvis på en anden sygesal. Der er forskellige oplysninger i Sigurds breve og $i$ Hans Lausten-Thomsens breve dateret 8. og 9. maj 1917. Oplysningerne i denne beretning er medtaget uændrede $i$ henhold til deres breve, men det må nok konkluderes, at Sigurds tids- og stedsangivelser er de korrekte. For eksempel oplysningen om, at Sigurd allerede kom til lazarettet $i$ Ath 30. marts 1917, JSS]. "Pludselig den 29. marts om natten fik jeg dårlig mave og høj feber. Lægen besluttede at sende mig på lazarettet. Om middagen gik det så løs i en gammel kassevogn - vi var nogle stykker. Undervejs havde vi det uheld, at en granat slog ned kort foran vognen og gjorde hestene så bange, at de rendte rundt og masede vognen i stykker. Vi måtte så gå det sidste stykke til fods. Har fået anvist en seng. Jeg blev sendt herhen på grund af fieberhaften durchsatz? [det er sandsynligvis dysenteri som Hans Lausten Thomsen skrev $i$ sit brev 8. maj, JSS], men føler mig snart igen alt for vel.« 
Krigslazaret nr. 23, 1. april 1917: "Alt er nu fredelig og idyllisk, og hvor er det dejligt atter at ligge i en blød seng og få alle lumper, utøj og snavs af kroppen.«

Krigslazaret nr. 23, 12. april 1917: »Det går godt fremad med helbredet - alligevel håber jeg at blive nogle dage her endnu. Rigtignok er det som følge af den nye engelske offensiv ikke let at opstille beregninger. Sandsynligvis rømmer vi lazarettet i nær fremtid, og det bliver måske lavet til feltlazaret. Trommeilden derude har i eftermiddag opnået en usædvanlig styrke. Alles sind er optaget af det. Der er åbenbart en stor sag i gang.«

Krigslazaret nr. 23, 26. april 1917: "Kampene viser sig som aldrig før. Måtte det dog snart gå mod den gode ende. Her $\mathrm{i}$ byen er livet ikke så stærkt berørt af krigen. I dag er der torvedag og mange mennesker i byen."

Lille, 27. april 1917: "Så sidder jeg atter i Lille og venter på toget til Ath - og kommer fra Douai [Douai ligger ca. $15 \mathrm{~km}$ bag fronten øst for Arras og Lens, JSS], hvor jeg blev sendt hen i går eftermiddags. Sagerne har jeg besørget. Skulle hente en melding fra et lazaret der. I Douai var alt fyldt med soldater. I lazarettet lå der en 300 englændere, mest hårdt sårede. Krigens gru slog én her på en særlig måde stærkt i møde. Jeg havde lejlighed til at kaste et blik ind i de stærkt fyldte sale og så dem ligge der, den ene ved siden af den anden, lemlæstede og lidende. I operationssalen var man travlt i arbejde. Ude i gården stod der 6 simple kister med dødens rov fra denne nat - alt den skrækkelige krigs følger. Røde Kors plejere og søstre øver her et stort og godt arbejde. - Sådan noget gør indtryk. Ikke heller glemmer jeg, da vi i går modtog en transport sårede direkte fra fronten ved Arras, blandt hvilke også var en hel del slemt medtagne. Her bag fronten møder sygdomme en på en anden måde end derude i skyttegravene."

3. maj 1917: "Jeg har lige fået til opgave igen at rejse til Douai med meldinger. Rejser her fra Aht i nat kl. 2 og vil være tilbage i morgen aften en gang, - ikke så galt en rejse."

Krigslazaret nr. 23 i Ath, 5. maj 1917: »Befolkningen her er ikke åbenbart fjendtlige, men dog heller ikke venlige, hvad jeg dog godt kan begribe. Vi har i dag igen modtaget en transport af sårede og syge, så vi snart er fyldt godt op."

[Ovenstående brev er det sidste fra Sigurds hånd, inden han blev virkelig alvorligt syg af lungehindebetrendelse og fik mere end 40 i feber. Den dansksindede læge Hans Lausten-Thomsen så Sigurd 8. maj for første gang og tog 
straks affare. Han skrev forst til Sigurds far $i$ Berlin og igen 9. maj til Bejstrupgård. Nedenstående indeholder korte citater fra læge Hans LaustenThomsens 15 breve, som lægen sendte til Sigurds forældre mellem 8. maj og 1. juni 1917, JSS].

8. maj 1917: "I morges da jeg kom ind i min sygesal i lazarettet, "Mittelschule« $i$ Ath i Belgien, læste jeg navnet Skrumsager over en seng. Det var din søn Sigurd, der har været syg i 8 dage og i nat er havnet på min sygeafdeling. Sigurd har en ret stærk lungehindebetændelse med høj feber og kan ikke selv skrive. Han er fuldstændig ved klar bevidsthed trods 40 grader i feber, hjertet arbejder godt, der er udsigt til, at den kraftige unge mand nok skal klare situationen, men i alle tilfælde er han ret svært syg, og jeg vil foreløbig føle mig forpligtet til at sende dig en lille daglig beretning."

9. maj 1917: »I går sendte jeg dig et brev til Berlin med fortællingen om din søn Sigurds sygdom. Han har jo ligget på lazarettet Lambrecht i Montigny-en-Gohelle i nærheden af Douai med dysenteri, der synes at forløbe meget let. Han blev så sendt til en afdeling for let syge i Ath i Belgien, men blev atter syg. Sigurd har lungehindebetændelse med udskillelse af en del væske i lungesækken. Denne væske er dog kimfri, og jeg har frem for alt andet i dag kunnet fastslå, at den er fri for tuberkulosebakterier. Han er dog ret svært medtaget og havde i går hele dagen temperaturer over 40 grader. Hjertet arbejdede i går aftes og endnu i morges ret uregelmæssigt og sløjt, men temperaturen var dog i morges sunket til 39 grader. Sigurd snakker om selv at skrive, for han havde lige fået brev om, at du nu var hjemme, men jeg sagde nej. Han får ikke lov til at skrive, før jeg er sikker på, at anstrengelsen ikke skader ham. Så længe skal jeg nok sende den daglige beretning.«

10. maj 1917: "Stor forandring er der ikke i Sigurds tilstand. I aftes gik det slet ikke godt. Temperaturen steg til 39,9, og pulsen var meget sløj og uregelmæssig."

11. maj 1917: "I aftes holdt temperaturen sig på 38 grader, men natten var ikke god. Din søn sov dårligt, fantaserede en del og havde i morges 38,5 grader. Vandmængden i lungerne er steget noget, og undersøgelsen var i morges en meget stor anstrengelse for ham. Sigurd er begyndt at spise. I går fik han ikke mindre end 4 æg.«

12. maj 1917: "Hjertet arbejder for øjeblikket godt og regelmæssigt, men hele venstre lunge er sat ud af funktion. Din søn har fået appetit. Han satte i dagens løb ikke færre end 6 æg til livs, drak en flaske rødvin og en dygtig portion mælk.« 


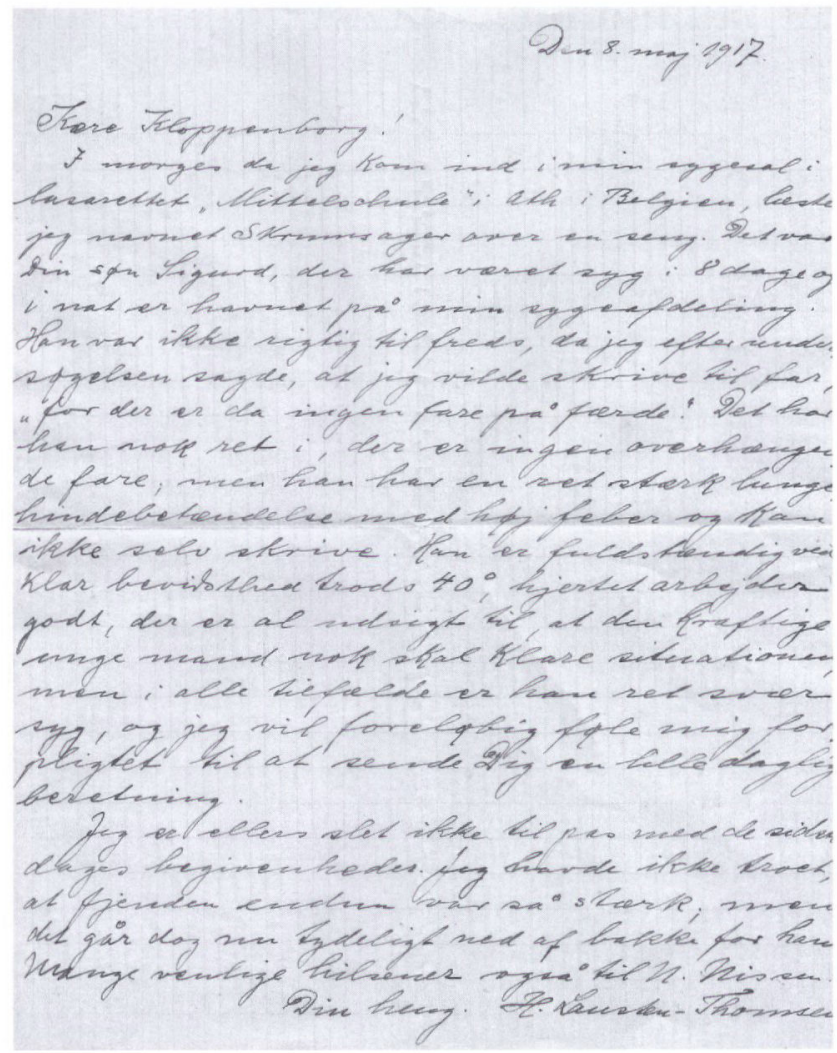

Læge Hans Lausten-Thomsens forste af $i$ alt 15 breve til Sigurds far, landdagsmand H.D. Kloppenborg Skrumsager, hvor han holder ham underrettet om sønnens tilstand. Bemærk samtidig den kodede meddelelse til sidst $i$ brevet: $)$ leg havde ikke troet, at fienden endnu var så stærk, men det går dog nu tydeligt ned af bakke for ham«. Med fjenden menes her Tyskland, hvilket han af hensyn til censuren ikke kunne skrive. Efter Genforeningen blev Lausten-Thomsen amtslage $i$ Tonder Amt. Han deltog aktivt $i$ det kulturelle liv $i$ Sønderjylland og var bl.a. $i 20$ år formand for Historisk Samfund for Sonderjylland.

13. maj 1917: "Tilstanden uforandret, men ret tilfredsstillende. Temperaturen i aftes 39,7 og i morges 38,4 . Pulsen god og regelmæssig «

14. maj 1917: »Beretningen kan ikke meddele om store fremskridt, heller ikke i dag. I aftes var temperaturen 39,7 grader og i morges 38,4 grader. Appetitten kommer, venstre lunge begynder at rore på sig, selv om den endnu svømmer i væske, hvad der har meget at sige. Hjertets arbejder bliver dag for dag solidere og mere regelmæssige.« 
15. maj 1917: "Endnu ingen større forandring. Temperaturen var $\mathrm{i}$ aftes 39,4 og her i morges 37,8 grader.«

16. maj 1917: »Temperaturen i aftes kun 38,2 , i morges 37,8 og pulsen regelmæssig og tilfredsstillende. Appetitten har det knebet med i går og i dag. Han takker for hilsenen fra sin moder. Jeg spurgte, om han ville læse brevet. Han tog det også i hånden, men gav sig ikke til at læse det. Han fandt anstrengelsen for stor.«

17. maj 1917: »Endelig kan jeg skrive et brev om fremskridt uden "men«-er. En tydelig bedring, selv om den endnu ikke er stor. Tak for både dit og din kones breve og venlige hilsner til jer begge.«

18. maj 1917: "I aftes var temperaturen 38,7 men efter en god nats søvn havde Sigurd i morges kun 37,0 grader. Første gang fri for feber.«

19.maj 1917: "Sigurds temperatur, der i aftes steg til 38,4, var i morges atter 37,0 grader. Han er betydelig livligere og kvikkere. Det synes at gå godt om end langsomt fremad, og jeg sender ikke mere daglige bulletiner, skal dog nok flittigt sende besked, indtil din søn selv kan skrive. Det vil forhåbentlig ikke vare længe.«

24. maj 1917: »Det går os vedblivende godt. Højeste temperatur siden jeg sidst skrev, 37,9 grader. Vi er tydeligt på den bedste vej, men den vil blive lang.«

27. maj 1917: "Det går vedblivende godt, men langsomt. Sigurd skriver jo selv nu, så jeg holder op med mine bulletiner. Jeg håber at kunne rejse hjem med 14 dages orlov sidst $i$ denne uge. Din søns tilstand er nu således, at han ikke volder mig den mindste betænkelighed i så henseende."

Skærbæk, 1. juni 1917: „Så svigtede jeg Sigurd og tog hjem med 14 dages orlov. Det kneb lidt for ham, da jeg sagde farvel. Det var ikke fri for, at der igen ville komme vand $i$ øjnene. Men det går ellers vedblivende godt fremad. Kræfterne tager tydeligt til. 4-5 uger bliver han sikkert endnu i Ath, og så tænker jeg, at jeg kan sende ham på et reservelazaret i Tyskland. «

[Herefter er det igen Sigurds breve, JSS].

Krigslazaret nr. 23 i Ath, 23. maj 1917: "Kære far, mor og søskende. I kære derhjemme. Tak for jeres breve. Jeg føler mig nu lidt bedre, men det har været drøjt, og der er endnu langt igen. Men først og fremmest må jeg takke Gud Fader, der så godt har stået mig bi. Måtte han sund og rask føre mig hjem til jer - hans vilje ske. Mange gode hilsner jeres Sigurd.« 


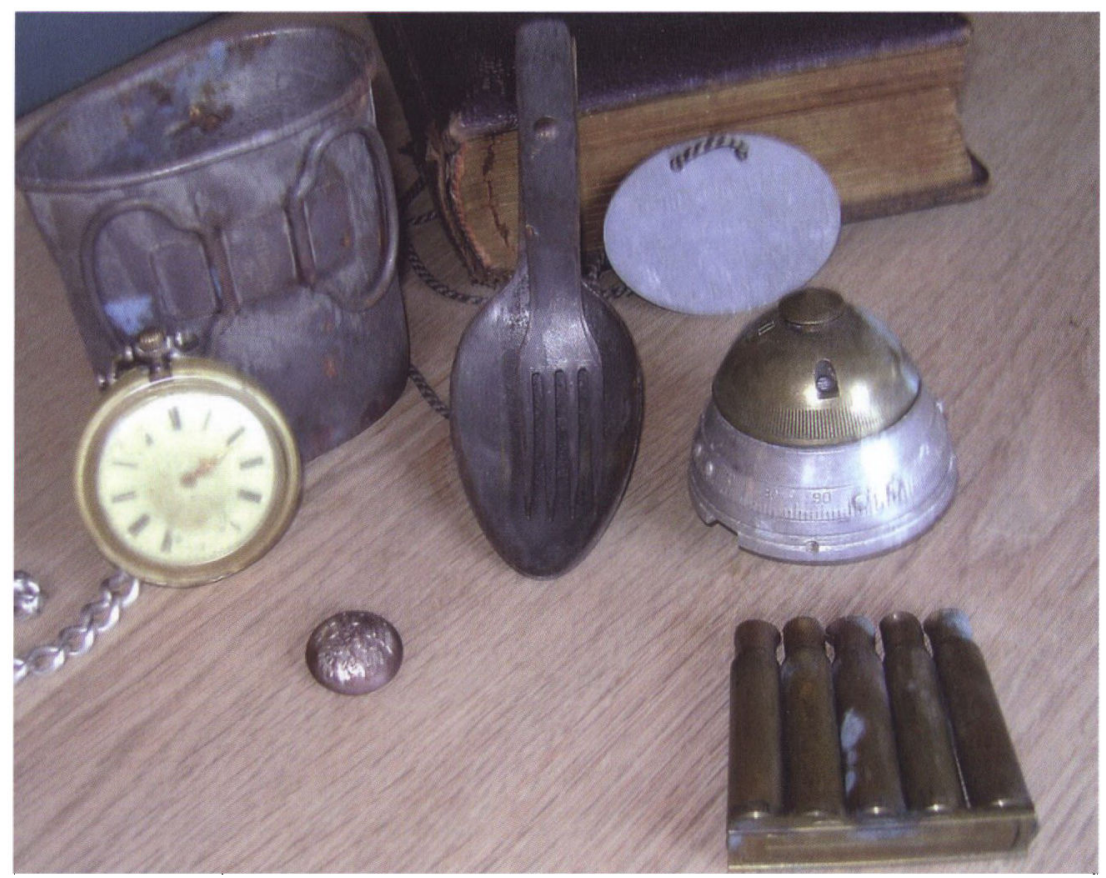

Sigurds souvenirs fra felten.

Krigslazaret nr. 23 i Ath, 24. maj 1917: „Endnu er det småt med mig, det går så langsomt, men jeg føler dog, at det bliver bedre. En lykke og glæde for mig er det med Dr. Thomsen. Så har jeg haft en sådan god bayersk søster til at pleje mig - hun har været som en moder for mig men nu er hun rejst i orlov - godt at jeg er kommet så langt med hende, for nu er jeg ikke så hjælpeløs mere. - Det er trange tider, men Gud Fader i himlen - måtte han snart bringe forløsning.«

Ath, 31. maj 1917: "Det kan endnu ikke nytte med besøg, som I spørger om. Jeg er alt for svag til at døje det - har ingen vilje og kraft til at beherske mig. - Det er ikke let, når det går sådan for en. - men lad os håbe på bedre tider. I går havde jeg en stor sorg i det, at læge Thomsen rejste på orlov. Først forlod min gode søster mig og nu min kære læge, men lidt på vej har de dog taget mig, så jeg nu knap er så hjælpeløs. I dag har der så været en ny læge, som jeg var meget glad for. Han skal også nok tage sig godt af mig, så jeg ser fremtiden godt i møde. Men en langsom og drøj historie er det. Den vil tage lang tid, 
så Thomsen vil sikkert nok nå at komme tilbage og kurere på mig igen. Han er vist på orlov en 14 dage eller 3 uger."

Ath, 15. juni 1917: [15. juni 1917 var Sigurd oppe at sidde et par minutter for forste gang. Han skrev hver dag fra lazarettet om sin tilstand og tanker. Jo nærmere tidspunktet kom for forældrenes tilladelse til at komme på besøg, prægedes brevene mere og mere af savn og sygdom samt häb om et snarligt gensyn. De kom på besog 17. juli og rejste igen 20. juli. Det var to måneder og 12 dage efter oplysningerne fra læge Hans Lausten-Thomsen om, at Sigurd var alvorligt syg. Jeg har ingen oplysninger om deres rejse, men den rejse gennem et krigshærget land med varemangel må have været vanskelig at planlægge og gennemføre, JSS].

23. juli 1917: „Kære far, mor og søskende! Tak for at I kom for at besøge mig - hvor slø̋j jeg så var, så har jeg dog haft meget ud af det. Jeg har fået meget mere ro i kroppen og nyt mod til at komme rigtig i gang igen. Ja, tak fordi I bar over med mig, nu jeg har været utålmodig og utilfreds. Jeg har kun lov til at sige tak for alt godt. Jeg betror Vorherre min sag, og han vil nok stå alle bi. Vær nu ubekymret - jeg er $\mathrm{i}$ gode hænder. Mange gode hilsner til jer alle.

Jeres hengivne Sigurd."

Elberfeld, 25. august 1917: [En forstad til Wuppertal $i$ Tyskland, JSS]. "Med lazarettoget forlod jeg så Belgien den 22. august og kom hertil i aftes og er blevet godt modtaget. Lægen her er civil, og søstrene synes flinke. Desværre er det her midt i byen, så her savner jeg atter den friske luft, men foreløbig må jeg se at komme til ro. NB. Skal hilse fra Thomsen - han kunne ikke længere beholde mig, sagde han, og det var da heller ikke meningen.«

Elberfeld, 31. august 1917: "Jeg er blevet røntgengennemlyst. I eftermiddag fik jeg pludselig ordre til at flytte andetsteds hen. Det her er et ganske lille lazaret med en 30 mand. Vi bor her i et villakvarter $i$ byens udkant - ret kønt, stor have osv. Lægen har jeg ellers ikke talt med, men det er ham, som har fået mig flyttet til mere ro og luft. Han kommer også her. Røntgenhistorien ved jeg endnu intet om. Venter meget på post - og også lidt på besøg."

Elberfeld, 17. september 1917: „Besøg af jer vil jeg være meget glad for, men jeg tror, at det for dig og søster, mor, vil være alt for vanskeligt især med sproget osv. NB. Jeg har i dag modtaget et lille brev fra Thomsen. Han er blevet forfremmet til overlæge.«

Elberfeld, 5. oktober 1917: "Jeg vil blive udskrevet den 13. oktober, og når jeg så kommer ud her fra, vil det være så vidt, at jeg straks 
kan rejse hjem, mente lægen. Efter alt dette at dømme kommer du vel næppe her og besøger mig, far, men det kunne se meget ud efter, at Köpenick [en forstad til Berlin, JSS] vil blive træfpunktet - lad os håbe det bedste.«

Elberfeld, 14. oktober 1917: »I morgen middag, mandag den 15. går turen til samlingsstedet i Düsseldorf og derfra videre til Köpenick. Måske vi allerede ses, når jeg når til Berlin, far."

Köpenick, 20. oktober 1917: "Far var herude i går. Orlovspapirer lader vente på sig."

Berlin, 4. november 1917: "Med hensyn til min sag står alt ved det gamle - men ellers er jeg meget nysgerrig efter at høre fra dem.«

\section{Efterskrift}

Den oprindelige årsag til, at jeg lånte Sigurds breve fra fronten af hans datter, Agnete, var myten om, at Sigurd var blevet alvorligt såret i Belgien, men blev reddet af en snarrådig læge, mens Sigurd lå i den del af lazarettet, hvor alt håb var ude.

En dansksindet læge ved lazarettet havde set navnet Skrumsager over en seng med en patient med mere end 40 grader i feber. Lægen genkendte navnet Skrumsager og kontaktede straks Sigurds forældre. Han fortalte dem om den meget alvorlige situation, Sigurd var i. Lægen bad forældrene om straks at tage affære, hvis de ønskede deres søn Sigurd levende hjem og ud af krigshelvedet. Sporenstregs satte Sigurds forældre alt $\mathrm{i}$ bevægelse og kørte i bil ned til Belgien gennem det krigshærgede Europa. De fik efter møje og besvær tilladelse til at køre derned og ankom til lazarettet kort tid efter. De fandt Sigurd, og de fik lov til at tage ham med $\mathbf{i}$ bilen hjem til et hospital $\mathrm{i}$ hjemstavnen.

Sigurds breve ændrer myten på mange punkter. Sigurd blev ikke såret, men fik pådraget sig en alvorlig lungesygdom. Sigurd blev syg i april 1917 ved fronten i Frankrig og ikke i Belgien. Lægen tog sig af behandlingen af Sigurd og informerede hver dag forældrene om sygdomstilstanden, indtil Sigurd igen kunne skrive. Forældrene fik først tilladelse til at besøge Sigurd godt to måneder efter, at de af lægen havde fået underretning om Sigurds alvorlige sygdom. Hvordan de rejste ned til lazarettet i Ath, Belgien, er uafklaret. Endvidere fik forældrene ikke lov til at tage Sigurd med hjem, også fordi han var for syg til en sådan rejse, og lægen har sikkert også forbudt det. 


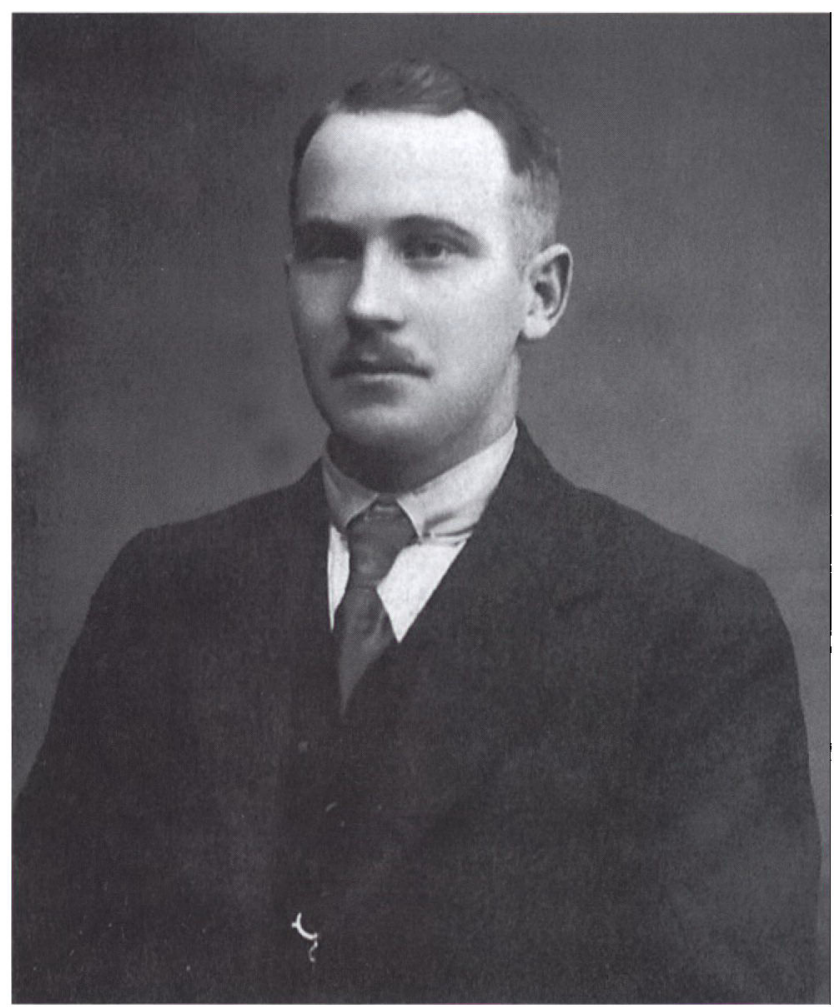

Sigurd efter 1. Verdenskrig. Sigurd købte $i 1924$ gården Kanekær $i$ Kelstrup og giftede sig samme år med sygeplejerske Christine Clausen fra Nordborg, som han havde modt på Vejle Tuberkulose Sanatorium, hoor han i 1920-21 var indlagt til behandling for tuberkulose. De fik fire børn. Ved den tyske besættelse $i 1940$ viste det sig, at Sigurd ikke havde fået dansk statsborgerskab. De tyske myndigheder krævede derfor, at Sigurd igen indtrådte $i$ tysk tjeneste, hvilket dog efter en besværlig proces blev undgået.

Sigurd kom forst hjem til Bejstrupgård i november 1917, og hans krigstjeneste var dermed endelig slut. Jeg vil lade Sigurd få det sidste ord fra hans stilehæfte på Askov Højskole kort tid efter afstemningen 10. februar 1920, hvor Sigurd havde nogle refleksioner om 1. Verdenskrig og om det at være dansksindet tysk soldat: "Når man ser på de senere års udvikling af den nationale kamp i Sønderjylland, må man i høj grad sande det gamle ordsprog, der siger, at når nøden er størst, er hjælpen nærmest. Gennem fire år formåede de tyske våben at holde hele verden i frygt og bæven, og det så længe ud, som om det ville blive Tyskland, der skulle komme til at diktere freden. Den bedste 
og kraftigste sønderjyske ungdom ødelagdes på valpladserne, alt gik tilbage og $\mathrm{i}$ forfald, man tabte modet, og håbet blev mange gange lille. Men så kom endelig omslaget i sommeren 1918. Det begyndte at lysne, og snart følte alle, at nu bar det nok frem mod befrielsens dag."

\section{Zusammenfassung}

Sigurd Kloppenborg Skrumsager schrieb gut 1000 Briefe an seine Familie in Københoved über seine Gedanken und Erlebnisse an der Kriegsfront während des ersten Weltkrieges. Er war dänisch gesinnt, aber zu deutschem Wehrdienst verpflichtet, falls er seine Zukunft in Nordschleswig verbringen wollte.

Sigurd wurde am 6. Juli 1893 geboren und war gerade erst 21 Jahre alt, als er am 12. November 1914 in Berlin zum Militärdienst einberufen wurde. Im März 1915 kam er an die Ostfront im damaligen Russland. Im Dezember $1916 \mathrm{kam}$ er an die Westfront bei Lens und Arras im westlichen Teil Nordfrankreichs. Sigurd wurde nicht verwundet, erkrankte aber an der Front im März 1917 an Rippenfellentzündung und Tuberkulose und kam ins Kriegslazarett Nr. 23 in Ath (Belgien). Später wurde er zur Erholung nach Deutschland geschickt, bis er im November 1917 zur Erholung zu Hause in Københoved ankam. Damit war der Kriegsdienst für ihn zu Ende. Zur Information über seine Krankheit dienen auch 15 Briefe, die der Arzt Hans Lausten-Thomsen an die Eltern Sigurds schrieb. Hans Lausten-Thomsen war ebenfalls dänisch gesinnt und zum deutschen Militärdienst einberufen, er war im Kriegslazarett Nr. 23 in Ath tätig. In seinen Briefen berichtet er ausführlich über die Krankheiten und die Entwicklung Sigurds. Es ist kaum zu bezweifeln, dass Sigurd durch den Arzt von dem Schicksal verschont blieb, dass 5.000 andere dänisch gesinnte Soldaten erlitten in einem Krieg, der nicht ihr Krieg war.

Trotz der heftigen Erlebnisse während des Krieges und der äußerst schweren und langen Tuberkuloseerkrankung und mehreren Krankenhausaufenthalten entwickelte sich Sigurd als erfolgreicher Landwirt in der Nähe von Haderslev. Er heiratete und wurde der Vater von vier Kindern. 